\title{
The analysis of chants from church psaltickhia of the metropolitan of Bucovina. Dr. Silvestru Morariu- Andrievici, first transcription of the traditional church music, psaltic, romanian, on linear notation in comparison with other similar chants from our country
}

\section{Costel-Mirel NECHITA*}

Abstract: Romania is a country which includes several provinces. Some of these, Bucovina, Transylvania, Banat and Oltenia, were occupied, in the XIIth-XIIIth centuries, by the Austro-Hungarian Empire. Although the occupation was long lasting, however, the Romanians did not lose their identity, culture, language and faith. In order to cope with all kinds of attempts in Bucovina, cultural societies were set up by the personalities of the time, among which we mention Metropolitan of Bucovina Dr. Silvestru-Morariu Andrievici (1818-1895), whose name, besides many others, is linked the school history and culture in Bucovina. Also, related his name is linked the Church's Psaltickhia, the first transcription of a part of the traditional church music, psaltic, Romanian, on the linear notation, a national and universal value document. In this study we will analyze this document in comparison with the Church Chants according to melodies of the eight voices collected in Transylvania and published by Father Dimitrie Cuntanu in 1890, and with the chants from the Romanian Anastasimatarele chosen and edited in the Uniformed Anastasimatar-Vecernier or

* PhD, Lecturer, at the Faculty of Orthodox Teology, „1-st December 1918” University of Alba Iulia. Romania. 
the evening Saturdays Vespers Chants after the eight church voices of Nicolae Lungu, Grigore Costea and Ion Croitoru. The purpose of the analysis is to see whether, under the occupation, the Romanian lands have kept and cultivated their church musical values, as happened at the level of the whole country, and if these values are linked with the unity of other Romanian Principalities and if there is unity in the church chants between the church composers from our country.

Keywords: Bucovina, transcription, church music, Byzantine, Vespers, Anastasimatar, voices, candence, tierce

The first concrete step in transposing the music of Byzantine tradition on linear notation was made in our country by a Bucovinean in 1879, in the person of the Metropolitan dr. Silvestru Morariu-Andrievici, a symbol of serving the altar and nation, the literature and pedagogy in Bukovina, through the Church Psaltickhia, the first transcription of a part of the traditional, psaltic, romanian church music on the linear notation. This step was taken three years before the demarches on this issue had began in 1881 by the famous Memorial about the church song of bishop Melchisedec Stefanescu of Roman, sent to Cernauti in 1881. In this Memorial, the Metropolitan Silvestru Morariu-Andrievici responded in a letter demonstrating his great intellectual capacity, the providential personality for the time and the historical conditions in which he lived, the openness and knowledge he had, as well the power of suggestion at national, civil and church level, regarding the reform of liturgical chants. "If the Holy Synod, as I have no doubt that will vote for the law project, and the Minister of Cults will execute those decided, will result very well for the liturgical cult, not only in the Kingdom of Romania, as well as 
in other countries populated by Romanians, where this reform of liturgical chants will undoubtedly be adopted"1.

This study is dedicated to the analysis of the Church Psaltickhia opera of the Metropolitan of Bucovina, and its echoes in and from the Romanian Principalities. The purpose of the analysis is to find out whether there is unity in the church chant between the church composers of the Romanian Principalities occupied by the Austro-Hungarian Empire and the unoccupied Empire territories.

The analysis of the eight church voices, concerning the chants, Lord, I call upon Thee, and Let my prayer arise, the Troparion of the Resurrection will have the following pattern:

1. The Presentation of the voices scale from Church Psaltickhia and the Church Chants according to the melodies of the eight voices, compared to the gamut of the Grammar of the "psaltic» church music, common with the ones used in the chants of the Anastasimatare and those of the standardized Anastasimatar - Vecernier or the Vespers Chants of Saturday evening on the eight church voices. As this opera will be used, comparatively, for analysis, we will indicate its name when we will present the scales of voices as being common to those in the Grammar of the "psaltic» church music.

2. Arguments by which we will show the similarities or differences between the steps of the two operas, the Church Psaltickhia and the Church Chants according to the melodies of the eight voices and the original ones of the church musical voices, byzantine, presented in the Grammar of the "psaltic» church music. It happens in some voices (to both authors) that the ladders used to the Lord, I call upon Thee and Let my prayer arise are not common with those used in the Troparion of the

${ }^{1}$ Viorel Cosma, Musicians from Romania. Bibliographic Lexicon, vol. VI, Bucharest: Musical Publishing House, 2003, p. 232. 
Resurrection. That is why the first two songs will be treated differently by Troparion.

3. Comparative examples that will highlight the source of inspiration for the chants of the Church Psaltickhia and those of the Church Chants according to the melodies of the eight voices, as well as the similarities and differences between them and the Anastasimatarele before their moment writing and the echoes of these songs in other Anastasimatare, appeared later on.

In order to observe the level of musical knowledge of the authors at the time of writing, and thus the evolution mode of the transcription of chants on the linear notation, we will give in comparative examples the identical transcription of the chants by each author, as follows:

-at the Church Psaltickhia by including in measures and without lasting legato;

-the Church Chants according to the melodies of the eight voices by including in measures, with a lasting legato;

-the other Anastasimatare before and after 1879, by including in measures (though not absolutely necessary), without lasting legato;

-to the standardized Anastasimatar -Vecernier or Chants of the Vespers on the eight voices by framing them in measures and with lasting legato, half-identical rendering of the chants written in this opera. By enforcing the chants of the other Anastasimatare, I watched the preservation of the unity with the first two operas, in the linear musical rendering.

In order to maintain the analysis very close to the original and to form a correct view on the reference opera, at Church Psaltickhia, apart from the analysis itself, we will reedem from the opera, at each voice, pictures with the vocal score original of the chants: Lord, I call upon Thee, Let my prayer arise and the Resurrection Troparion. 
We have not corrected any squeezed mistakes (especially related to the lasting legato) during the transcription of songs by the authors, or at their edition, because that is not the purpose of the opera, but we render the content of the transcribed chants as more identical with the original. For the voices in which the resemblance of the chants is more obvious, we will renounce for the detailed comparative examples. The same will happen to voices 2 -nd and 5-th, for which the two authors encounter some difficulties in transcription.

\section{1-st Voice}

l-st voice uses diatonic scale with key note on pa (re). Due to the law of sounds attraction almost always zo (si) in descending becomes ifes (flat). Sometimes, this change takes place at the second step, the note $v u$ ( $m i$ ) becoming ifes (flat).

In sticherarion tact there are imperfect cadences on $g a(f a)$ and $p a(r e)$ and finals in $p a(r e)$.

In irmologhion tact there are imperfect cadences on $d i(\mathrm{sol})$ and perfect and final in $\mathrm{pa}(\mathrm{re})^{2}$

Scale of 1-st voice, according to:

Example 1: Standardized Anastasimatar - Vecernier or the Vespers Chants of Saturday evening on the eight church voices and other Anastasimatare.

Example 2: Church Psaltickhia.

Example 3: Church chants according to the melodies of the eight voices.

2 Nicolae Lungu, Grigore Costea, Ion Croitoru, Grammar of the «psaltic» church music. Compared study with linear notation, Bucharest: Institutul Biblic și de Misiune al Bisericii Ortodoxe Române Publishing House, 1951, pp. 70-71. 

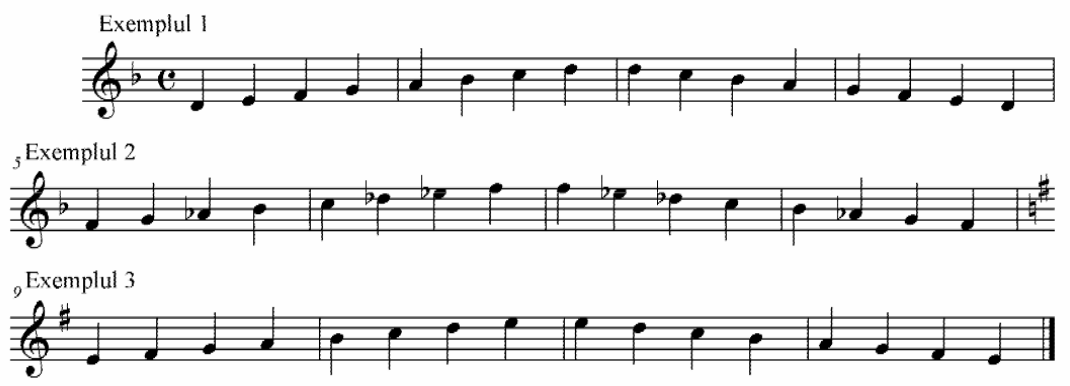

At 1-st Voice, in church Psaltickhia, the placement of si flat at key indicate two variants according to the rules of finding a mode: either we are in the major fa mode, or, in its relative, minor re. However, as the 1-st voice, according to its structure is minor, the fa major variant is excluded. However, the song often beats on the fa mode, begins with this note, preceded by mi flat, and places the final pacing also on the $f a$ note. It is noted, in this sense, that the necessary of knowledge, at least at the beginning of Psaltickhia's transposition, is somehow limited, the author guessing but not holding the relative of one mode, which, in the case of the first voice (major fa, relative minor re) would solve the problem, without any alteration. In fact, the composer guesses the fa minor mode (we say), but probably did not know much in this sense (at the beginning of the transposition) and transposes into what he mastered better, videlicet in major $f a$, with the alteration during the song, with flat, of note $m i$, la, and $r e$, thus transforming it into a minor fa. It alters, however, only re note with the flat, from the second octave, keeping the small tierce interval between $f a$ and $r e$ of the lower octave, thus framing in the structure of the 1-st voice, where zo (si) of the central octave is ifes (flat) in descending, due to the law of the attraction of the sounds, and in the lower octave, in the 
descending way of the song, it is often, naturally, the re-si becar range, under the tonic, being of a small third.

Even though they are not exactly the same, as melody, with the chants of the Anastasimatare older than 1879, the chants of Psaltickhia on 1-st voice (and on the other voices) are more familiar musically, pleasant to the hearing and in tone with the melodic formulas of those, having the perfect and final cadenza identical. Some of these formulas were taken from the Anastasimatarele older than 1879, being rendered approximately the same. Many of these formulas have also been taken over by the authors of Anastasimatare after this year, sometimes identical, other times very similar.

Dimitrie Cuntanu transcribes the l-st voice in the $m i$ minor mode, also taking into account the small third under the tonic from the inferior octave, by altering the do note with sharp. voice.

Comparative examples from Lord, I call upon Thee, 1-st

Example 1: Church Psaltickhia, p. 1.

Example 2: Church Songs according to the melodies of the eight voices, p. 1.

Example 3: "Anastasimatariu bisericescu" - Church Anastasimarion, by Hieromonk Macarie, p. 1.

Example 4: The New Anastasimatar, translated and composed according to the old system of Serdar Dionisie Fotino, by Anton Pann, p. 2.

Example 5: Rhythmic Anastasimatar, including the Chants of the Eight Voices as well as the Praisings of the 11 Gospel of the Resurrection by Nicholas Severeanu, p. $7^{3}$.

${ }^{3}$ The melodic formula is taken up identically by Nicolae Barcan in the Small Practical Anastasimatar, Bucharest: The Church Books Printing House, 1922, pp. 5-6, by Victor Ojog in Anastasimatar, Neamt Monastery Printing 
Ex. 1

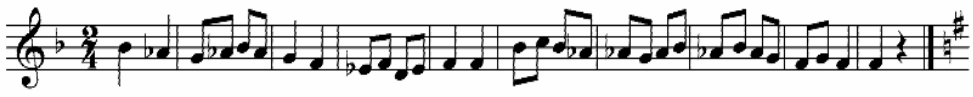

gla a su u u u ul ru u u gã ã ciuu u ne e e i me e e e e e le

Ex. 2

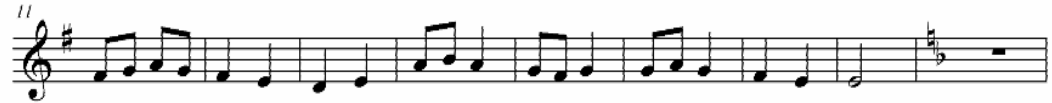

gla a a a a sul ru gã ciu $u$ ni $i$ me e e e e le

Ex. 3

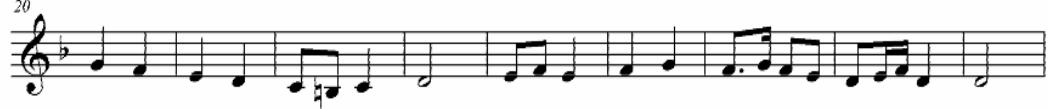

Ex. 4

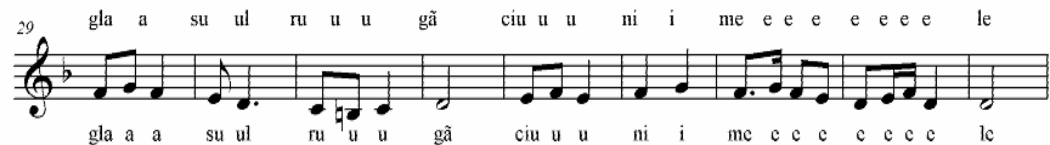

Ex. 5

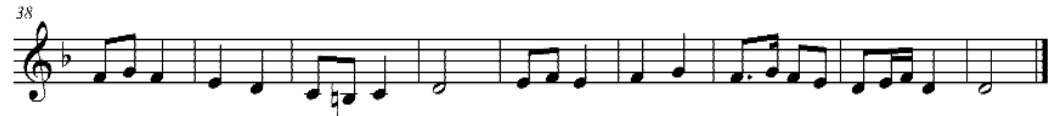

gla a a su ul ru u u gã

ciu u u ni $\mathrm{i}$ me c c c c c c c e lc

Comparative examples of the Troparion of the Resurrection, 1-st voice.

Example 1: Church Psaltickhia, p. 14.

Example 2: The church chants according to the melodies of the eight voices, p. 2.

Example 3: "Anastasimatariu bisericescu"- Church Anastasimarion, by Ieromonk, pp. 13-14.

Example 4: The New Anastasimatar, translated and composed according to the old system of Serdarian Dionisie Fotino, by Anton Pann p. 18.

House, 1943, p. 1 and by other authors. It is redeemed very close by Nicolae Lungu, Grigore Costea, Ion Croitoru, standardized Anastasimatarul - Vecernierul or vesper chants of Saturday on the eight church voices, Bucharest: Institutul Biblic și de Misiune al Bisericii Ortodoxe Române Publishing House, 1953, p. 16. 
Example 5: Rhythmic Anastasimatar, including the Chants of the Eight Voices as well as the Praising of the 11 Gospels of the Resurrection, by Nicolae Severeanu p. 22.

Example 6: Standardized Anastasimatar-Vecernier or Vespers Chants on eight church voices, p. 53.

Ex. 1

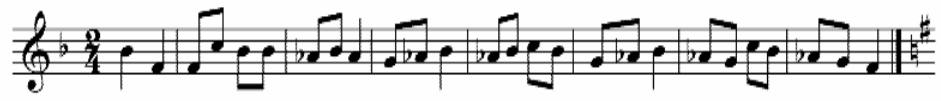

Pia tra fi ind pe cet lu i tã de e vrei si o sta sii strã ju ind precu ra at tru pul tau

Ex. 2

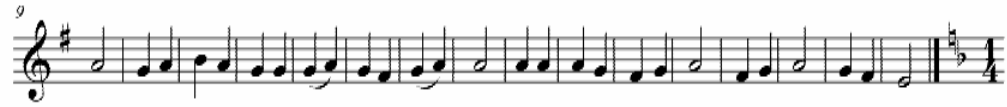

Ex. 3

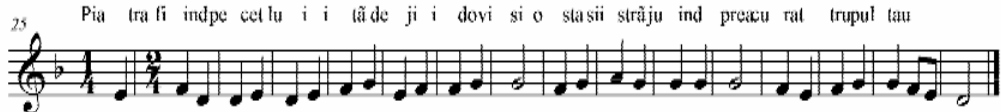

Pia a tra lind pecet lu $i$ tãde $j i \quad i$ dovi si o stasii strãju ind prexu ra at trupuul tau

Ex, 4

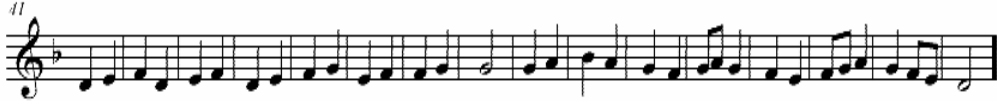

Pi a a tra fínd pecet lu $i$ tã de ji $i$ dovi si o stasii strãju i iind preacu ra a at trupuul tau

Ex. 5

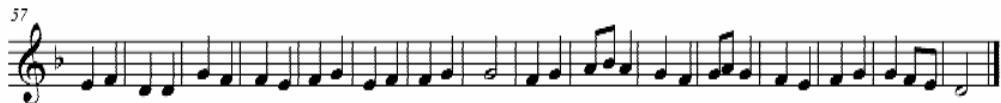

Pi a tra fi indpe cetlu i i tä de ji $\mathrm{i}$ dovi si o sta asii sträju $\mathrm{i}$ iind precu ra at trupu ul tau

Ex. 6

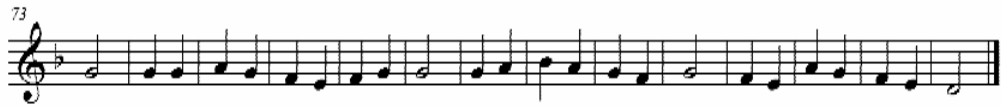

Pia tra fi ind pe cet lu i tơ si o sta sii strá ju ind prea cu ra a at tru pul tau

\section{2-nd Voice}

According to the Grammar, 2-nd voice has its own chromatic scale, based on $d i$ (sol) and sometimes in $v u$ and $n i$ ( $m i$ and do). Cadences of the 2-nd voice are:

- in the sticherarion tact, imperfect cadences on $d i, v u$ and zo (sol, mi and si) and sometimes on ni (do) of down, perfect cadence on di and vu and finals on di (soil). 
- in the irmological tact we have the following cadences: imperfect on di (soil), perfect on $v u(m i)$ and finals on $d i(s o l)^{4}$.

The Scale of the 2-nd voice, according to:

Example 1: Standardized Anastasimatar-Vecernier or Saturday Vespers Chants on eight church voices other Anastasimatare.

Example 2: Church Psaltickhia.

Exemple 3: Church chants according the melodies of eight voices.
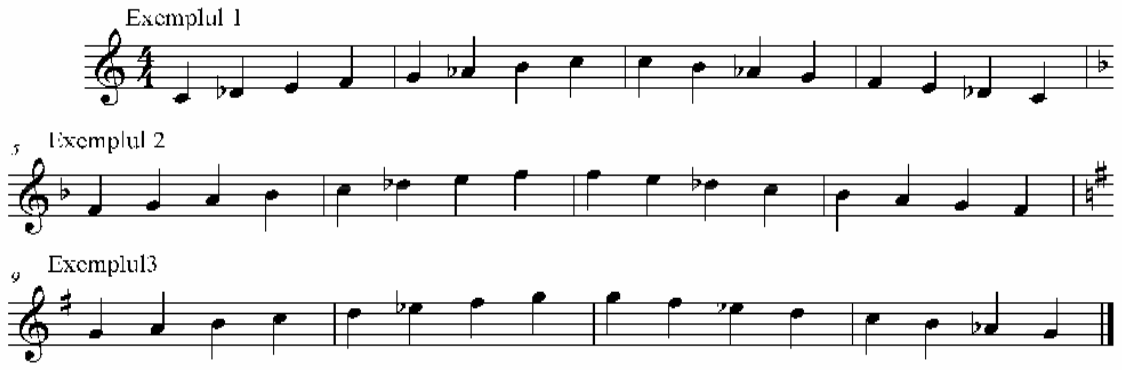

The Church Psaltickhia transcribes the 2-nd voice too in major fa and alters along the way the mi notes from the lower octave and $r e$ from the central octave. Thus, two possibilities are creating:

1. Whether we are in the si flat major mode, which may be proper to any voice with a diatonic scale, thought from this stage, but certainly not to the 2-nd voice. Alteration of sol with flat would have solved the second tetracord problem. We were no longer interested in altering the 2-nd step (do) with flat, in order to have the full scale of the second voice, as the melody never descends, in this case, during the chants of Psaltickhia up to the tonic.

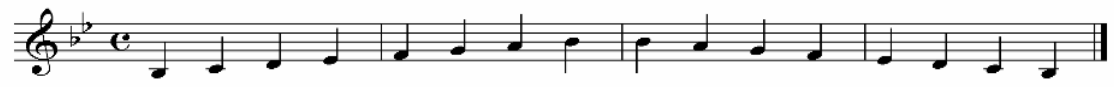

${ }^{4}$ Nicolae Lungu, Ion Croitoru, Grigore Costea, op. cit., p. 85. 
2. Whether we are in major fa, with the 6-th step lowered, which would mean half of the second voice, videlicet, only the second tetradorde is identical to the Byzantine second voice.

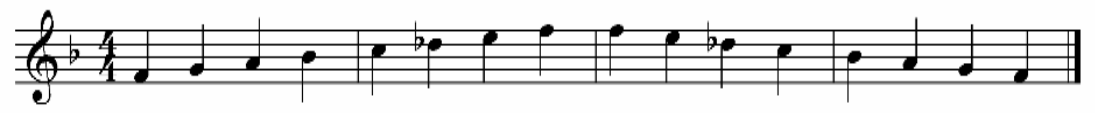

However, in this case the melody should, according to the Grammar, to carry out around the top quint, or the chants always cadence on the fa tonic. In other words, we can say that in the Psaltickhia chants, at the second voice, is used the proper chromatic scale based on the tonic ( $f a$ ) with the first diatonic tetracord and the second chromatic. At Silvestru MorariuAndrievici lacks the semitone between the 1-st and 2-nd stages from the first tetracord.

Dimitrie Cuntanu transcribes the chants in the sol major mode, altering only in descending the note la with flat, thus approaching the melody to the second Byzantine voice, with the 2-nd and 6-th steps decreased and seconds increased between the 2-nd and 3-rd stages, in the first tetracord, of 6-th and 7-th, in the second tetracord.

If Dimitrie Cuntanu solves the problem of the first tetracord, by altering, especially in descending, of the 2-nd stage, Silvestru Morariu-Andrievici has unaltered pace, in the first tetracord, both in climbing and in descending. Both authors encounter difficulties in redeming the 2-nd and 6-th voices. That is why, in these cases, we will render, only the comparison between the two operas.

Comparative examples from Lord, I call upon Thee, 2-nd voice

Example 1: Church Psaltickhia, p. 17.

Example 2: The church chants according to the melodies of the eight voices, p. 3. 
Ex. 1
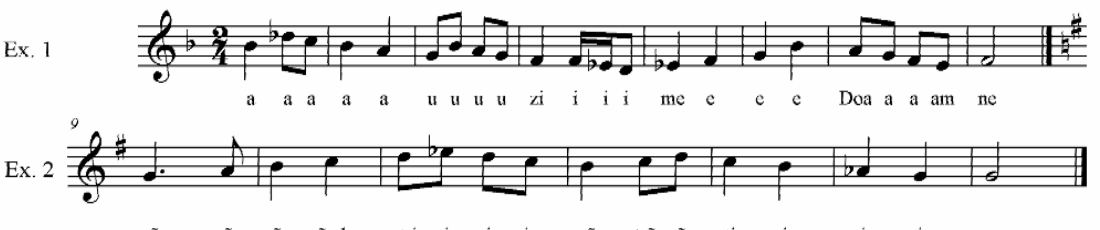

$\begin{array}{llllllllllllllll}\text { cã } & \text { ã } & \text { ã } & \text { ãnd } & \text { stri } & \text { i } & \text { i } & \text { ig } & \text { cã } & \text { trã } & \text { à } & \text { ti } & \text { i } & \text { i } & \text { i } & \text { ne }\end{array}$

\section{3-rd Voice}

The third voice is very close (as a melody) to the two authors to the third Byzantine voice, with the melodic line close to that of Anastasimatarelor.

Although the scale of the third voice evolve into a minor form, resembling much with the melodic lines of the 2-nd and 5th voices, thought it still has as tonic the basic tonality from which derives, the major one, preparing the final cadence (in this form) only in the last moment.

The Scale of the 3-rd voice, according to:

Example 1: Standardized Anastasimatar-Vecernier or Saturday Vespers Chants on eight church voices and other Anastasimatare.

Example 2: Church Psaltickhia

Exemple 3: Church chants according the melodies of eight voices
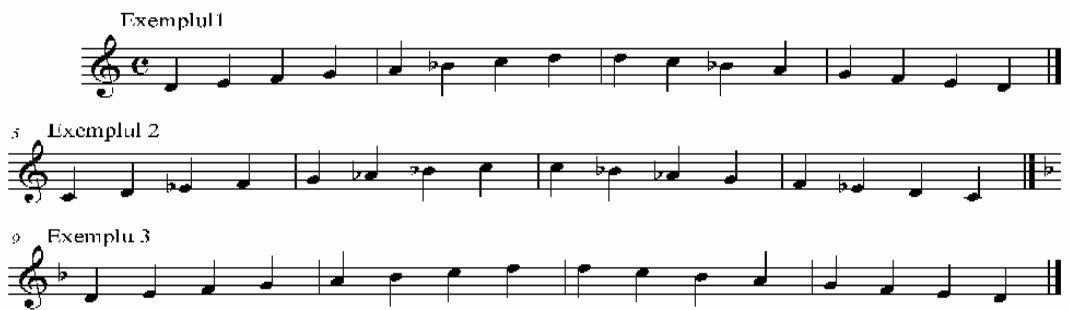

In Church Psaltickhia, the 3-rd voice srendered graphically in the major Do, but it alternates with flat, during the chant, the 
notes si mi (from the lower octave), and la from the central octave. According to the armor we can frame the mode in mi flat major or do minor. In the case of Psaltickhia, the melody of the 3-rd voice developed in do minor, with the final cadence on the major relative, mi flat major.

Dimitrie Cuntanu correctly transcribes the 3-rd voice, in the major fa mode, with some cadences on the relative minor, re and with alteration, especially when the melody follows an ascending stream, of the note si flat with si becar, fact often found in uniformed chants.

Comparative examples from Lord, I call upon Thee ... 3-rd voice.

Example 1: Church Psaltickhia, p. 22.

Example 2: Church Chants according to the melodies of the eight voices, p. 6 .

Example 3: Anastasimatariu bisericescu - Church Anastasimarion, by Ieromonk Macarie, p. 62. Melody taken over by Dimitrie Suceveanu in: Anastasimatariu bisericescu ${ }^{5}$ and Victor Ojog in: op. cit., p. 63.

Example 4: The New Anastasimatar, translated and composed according to the old system of Serdar Dionisie Fotino, by Anton Pann, p. 72.

Example 5: Rhythmic Anastasimatar, including the Chants of the Eight Voices as well as the Praisings of the 11 Gospel of the Resurrection by Nicholas Severeanu, p. 77, taken over identically by Nicolae Barcan, in op. cit., p. 39.

${ }^{5}$ Dimitrie Suceveanu, Anastasimatariu bisericescu, Iaşi: The Holy Metropoly Printing House, 1848, p. 81. It is a re-editing of the Anastasimatariului bisericescu of the Hieromonk Macarie, printed in Vienna in 1823 and reedited in Buzau in 1856, with some additions made by the Dimitrie Suceveanu. 
Example 6: Standardized Anastasimatarul -Vecernier or Vespers Chants on eight church voices, p. 92. Identic formula, melodically, with that of Example 4.

Ex. 1

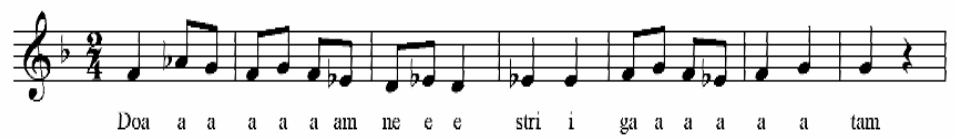

Ex. 2

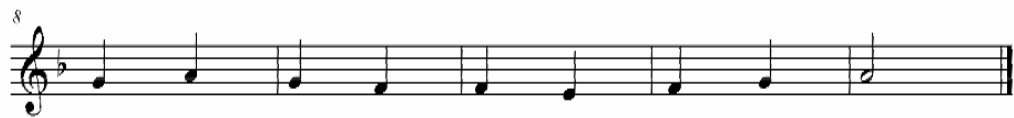

Doa a a an ne stri ga tam

Ex. 3

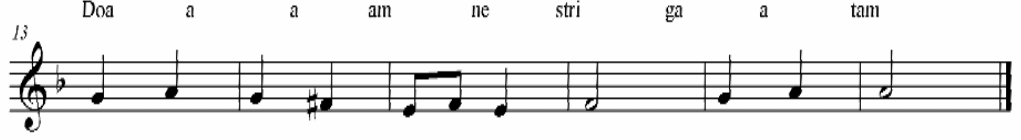

Ex. 4

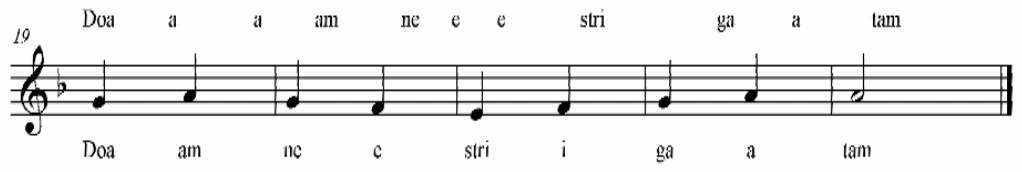

Ex. 5

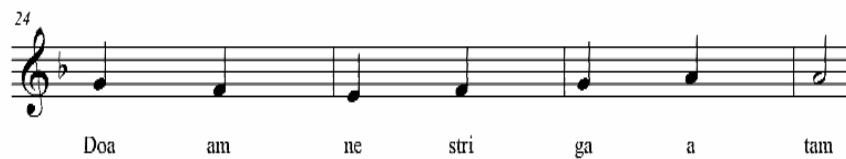

Ex. 6

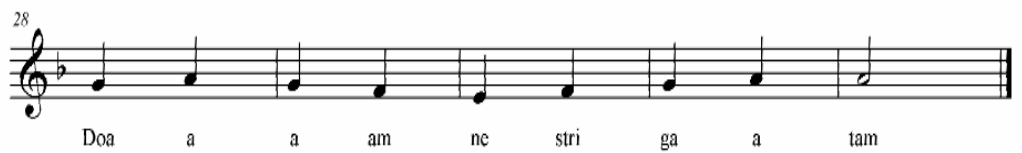

Comparative examples from the Resurrection Troparion, 3-rd voice.

Example 1: Church Psaltickhia, p. 15.

Example 2: Church Chants according to the melodies of the eight voices, p. 8.

Example 3: Anastasimatariu bisericescu, p. 75, formula identically taken over by Nicolae Barcan, in: op. cit., p. 45 and Victor Ojog in: op. cit., p. 74. 
Example 4: The New Anastasimatar, translated and composed according to the old system of Serdar Dionisie Fotino, by Anton Pann, p. 18.

Example 5: Rhythmic Anastasimatar, including the Chants of the eight voices as well as the Praisings of the 11 Gospel of the Resurrection by Nicholas Severeanu, p. 86.

Example 6: Standardized Anastasimatarul-Vecernier or Vespers Chants on eight church voices, p. 118.

Ex. 1

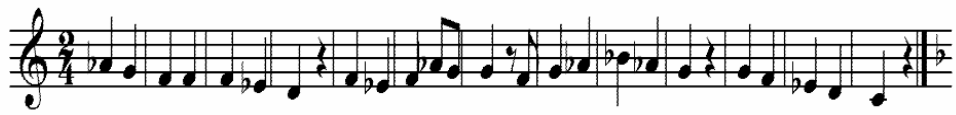

Sã se ve se lea a scã ce e le cee resti si sã se bu cu re ce le pãmîn testi

Ex. 2
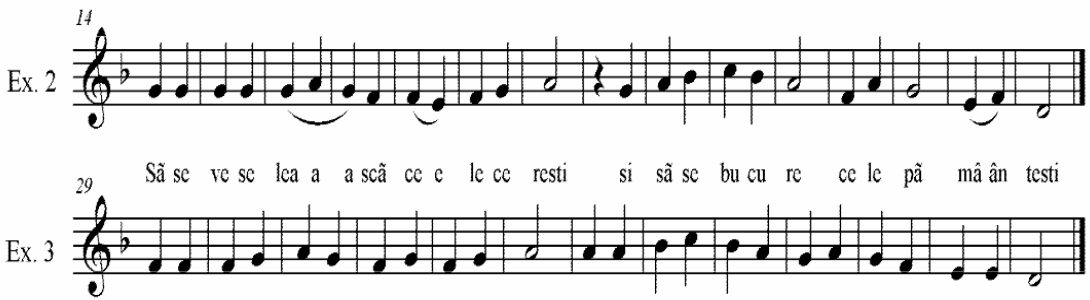

Sã se ve se lea a scã ce le ce resti si sã se bu u cu re ce le pã mân te esti

Ex. 4

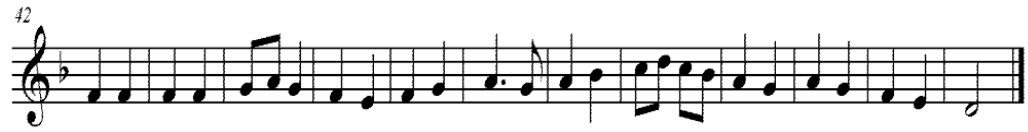

Sã se ve se lea a a scã ce le ce resti si sã se bu u cu u re e ce le pã mân testi

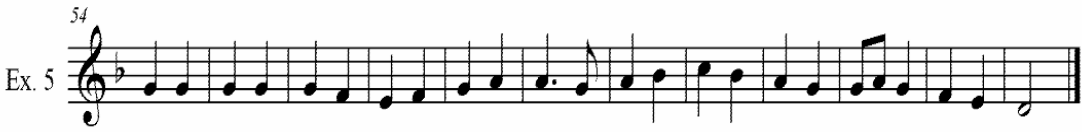

Sã se ve se lea a scã ce le ce resti si sã se bu u cu re ce e le pã mân testi

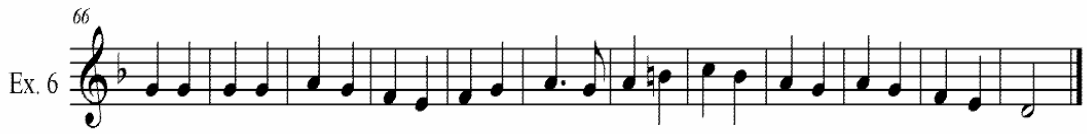

Sã se ve se leas cã ce e le ce resti si sã se bu u cu re ce le pã mân testi 


\section{4-th Voice}

The 4-th voice uses the diatonic scale of the 8-th Voice.

According to the tact, the cadence is done on two steps:

-on the di (sol) in the papadic tact and

-on $v u(m i)$ in sticherarion and irmological tact.

Scale of the 4-th voice, according to:

Example 1: Standardized Anastasimatar-Vecernier or Saturday Vespers Chants on eight church voices, p. 118.

Example 2: Church Psaltickhia.

Example 3: Church Chants according to the melodies of the Eight Voices.

Exemplul 1

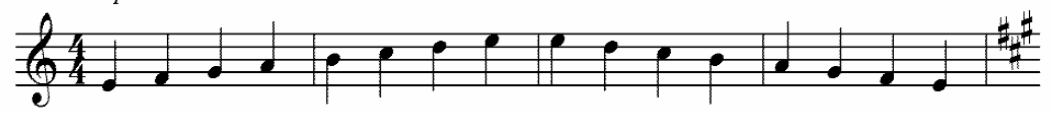

Exemplul 2
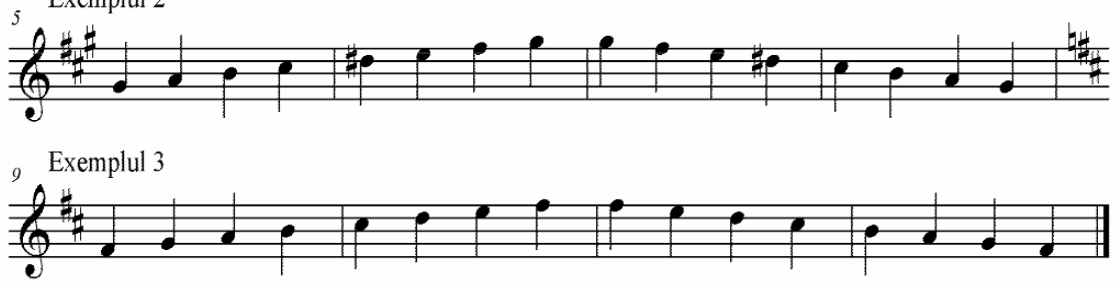

In the Romanian Psaltickhia the chants are transcribed, according to the key armor, in major la. Altering, however, along, the note re with sharp, mode becomes actually, major mi. The author begins and cadens at the end of chord tierce, the sol with sharp, as in the authentic 4-th voice, where, in one of the variants, the structure of the mode is as major do, the chant starting and ending on the tierce, mi, which in 4-th voice becomes tonic. So, in both cases, Silvestru Morariu-Andrievici uses the variant of the sticherarion and irmological tact, with the cadence on the mode tierce, which thus becomes key note. At Lord I cried and Let my 
prayer be set forth before, Silvestru Morariu-Andrievici cadences frequently, inside the chant, on the 2-nd stage and only the final cadence is set on 3-rd stage, became tonic.

In Church Psaltickhia, the Troparion of Resurrection is written, according to the armor, in the key note la flat major (minor fa), but the alteration on movement of sol note with flat change the chant in major re flat mode, the final cadence being also on the chord tierce (natural fa).

In the Church chants after the melodies of the eight voices, the 4-th voice is rendered in major re with the beginning and the final cadence on the tierce sharp fa. It is taken into account, especially at Dimitrie Cuntanu, of the structure of the 4-th voice, with the 5-th step mobile (both naturally ascending and flat in the descending), fact caused by the law of the attraction of sounds, a situation especially encountered in the leghematic irmological chant.

Dimitrie Cuntanu cadences inside the chant on 3-rd and 5th stage and the final cadence he places it on 3-rd stage, which becomes key note/tonic. The chants melodies are similar as structure (scale) at both authors and to the other Anastasimare, but more different, than other voices, regarding the melodic way.

Comparative examples from Troparion of Ressurection, 4th voice

Example 1: Church Psaltickhia, p. 31.

Example 2: Church Chants according to the melodies of the eight voices, p. 10.

Example 3: Standardized Anastasimatar-Vecernier or Vespers Chants on eight church voices, pp. 153-154. 
Ex. 1

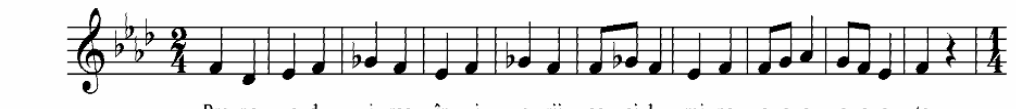
Pro po ve du $i$ rea în vi e rii ce ei lu mi na a a a a a a te

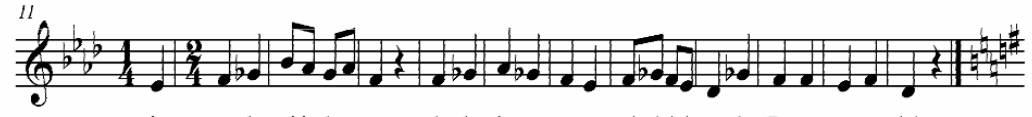
în te le gâându u o de la ân ger u ce ni $\mathrm{i}$ i i te le Doom nu u lui

Ex. 2
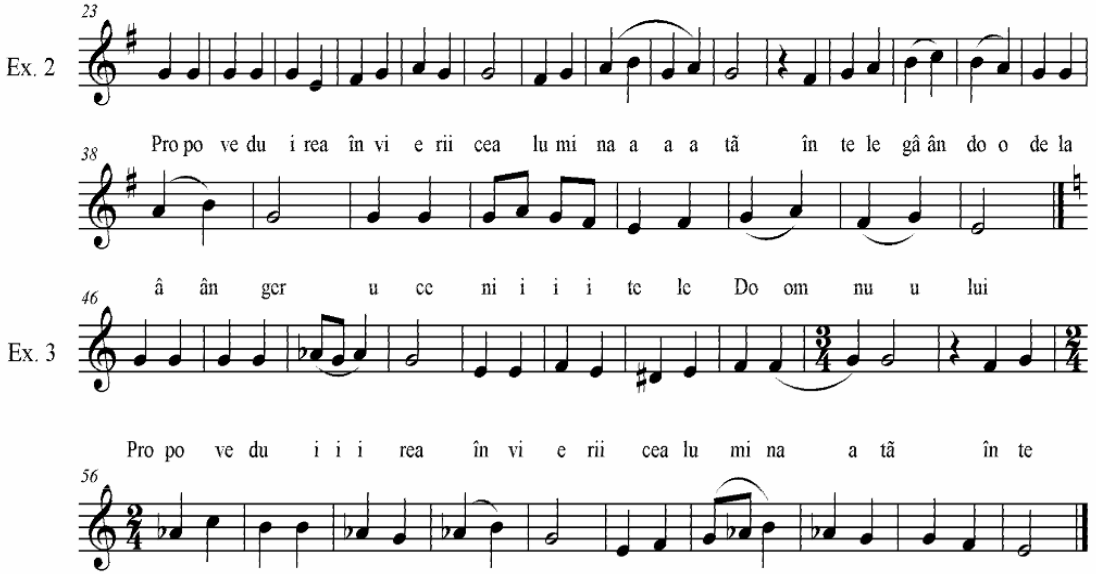

le gân du o de la $\hat{i}$ in ger $u$ ce ni $i$ te le Dom nu lui

\section{The 5-th Voice}

The 5-th voice uses the same scale as 1-st voice. It has two key notes:

-in the sticherarion tact the basis is pa (re), and

-in the irmological tact, the base is ke (la).

The Scale of the 5-th voice, according to:

Example 1 a: Standardized Anastasimatarul -Vecernier or Saturday Vespers Chants on eight church voices, sticherarion tact.

Example 1 b: Ibid., irmologic tact.

Example 2 b: Ibid., irmologic tact. 
Example 3 a: Church Chants according to the melodies of the eight voices, sticherarion tact.

Example 3 b: Ibid., irmologic tact:
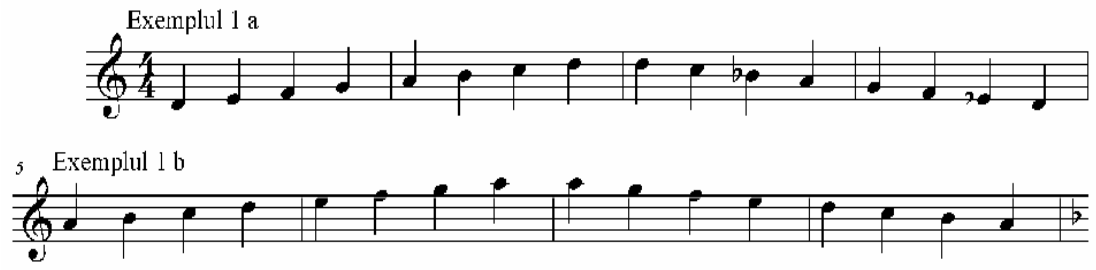

- Exemplul 2 a

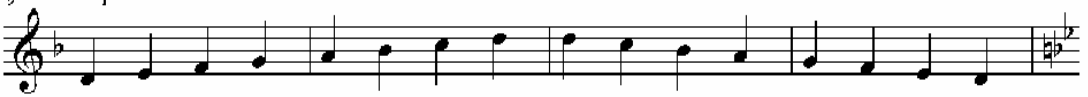

13 Exemplul 2 b
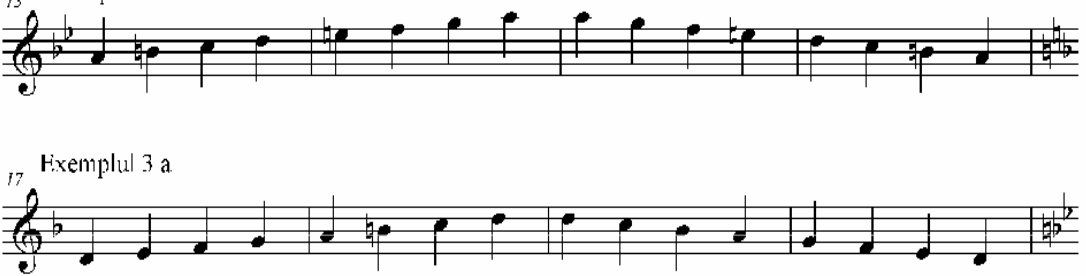

lixemplul $3 \mathrm{~b}$

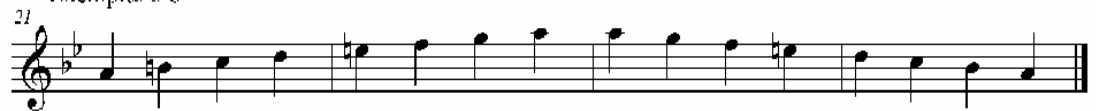

The Church Psaltickhia combines at Lord I cried and Let my prayer be set forth before Lord, the sticherarion tact with that irmological one. For the sticherarion tact intuits a kind of minor re (although the graphic design of key note armor is a major si flat or minor sol, thing which is not suitable for the inner hearing of the author in redemeeing the Vth voice). That's why, he always replaces everytime mi flat with mi natural, turning the key note into minor re. Sometimes it cadences on sol note, thinking the melody in minor sol and using in this case the note sharp fa as 
sensible. When the chant candences sticherarion, videlicet, on re, the author alters the fa note with the natural, thinking in minor re. When it cadences irmologically, on the la note, by alteration of mi flat with mi natural and of the si note with si natural, the author leads to a minor la chant. When it cadences on the la note, every time it is helped by the sharp $f a$ note, which he spontaneously introduces in the melody way, without any prior training (in the case below fa natural imediatelly followed by sharp fa), and alternates in descending towards the formula of perfect cadence si flat with si natural, fact often met in psaltic church music.

Example from din Lord I cried ... voice 5-th, Church Psaltickhia, p. 34:
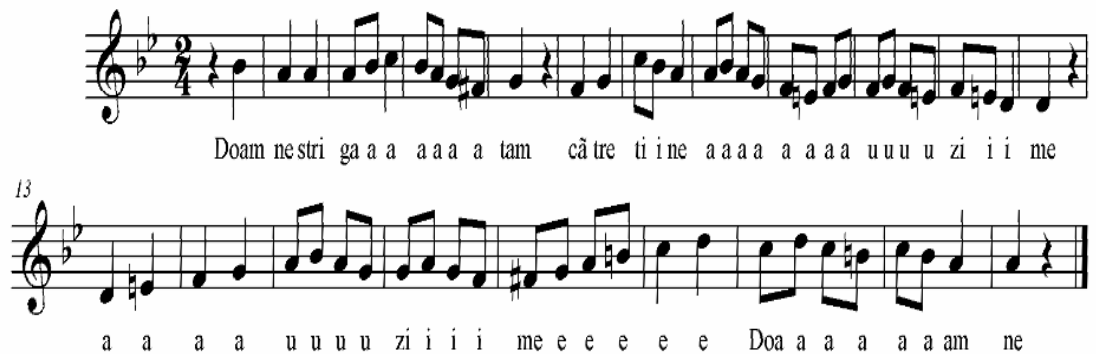

Starting with stichera, he renounces at mi flat from the key cadencing interiorly between the sticherarion and the irmological (on the re and on la), and finally, just the irmological, on the note la. Only at stichera he cadences on sticherarion, on re note.

In the Church chants according to the melodies of the eight voices, the 5-th voice (Lord, I have cried ... and Let my prayer be set forth before Lord ... ) is rendered in the minor re mode and the progress of the song oscillates between the sticherarion and the irmological tact with the alternation si flat and si natural.

The example of Lord, I cried ... the voice 5-th, the Church chants according to the melodies of the eight voices, p. 12: 

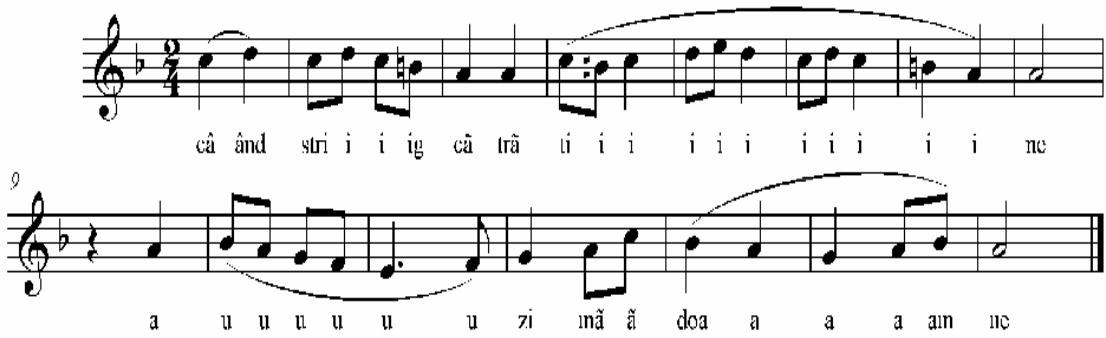

At Troparion, Silvestru Morariu-Andrievici realizes the inutility at key of flats correspondend to the si and mi notes, and renounces at them and alters si flat with si natural, only when he feels musically this necessity. It appears as a novelty element at the end, the note sol sharp, which, together with sharp fa, placed inside the la gamut, transforms it into melodic minor la, with the 6-th and 7-th steps altered ascending, and in descending returning to natural minor la.

Example of Resurrection Troparion, voice 5-th, from Church Psaltichkia, p. 38:

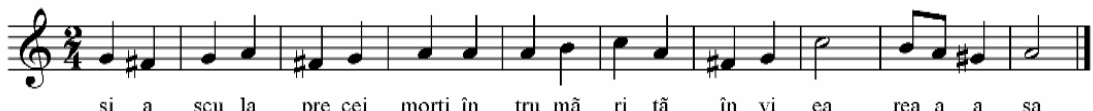

It thus redeems, the Troparion of the Resurrection of the 5th voice the irmological tact (ke ca from pa), with sol note as sensitive to the harmonic minor la mode. Melodic development is in tone with the compositional style of our church, psaltic tradition.

At Prosomia (Rejoice larder) cadences between sticherarion and irmologic, using when variant minor natural la, with the 6-th step oscillating, when variant minor la melodic. He sets the final cadence on the re note.

Alternates the chant between the minor re, with the 4-th step altered in ascending (sharp fa), or minor sol with sensitivity 
and minor la, with the step 6-th alterated in ascending (sharp fa) and with alternation and si flat-si becar.

Example of the Prosomia, Example from Prosomia, voice 5-th, Rejoice pantry ..., Church Psaltickhia, pp. 38-39:
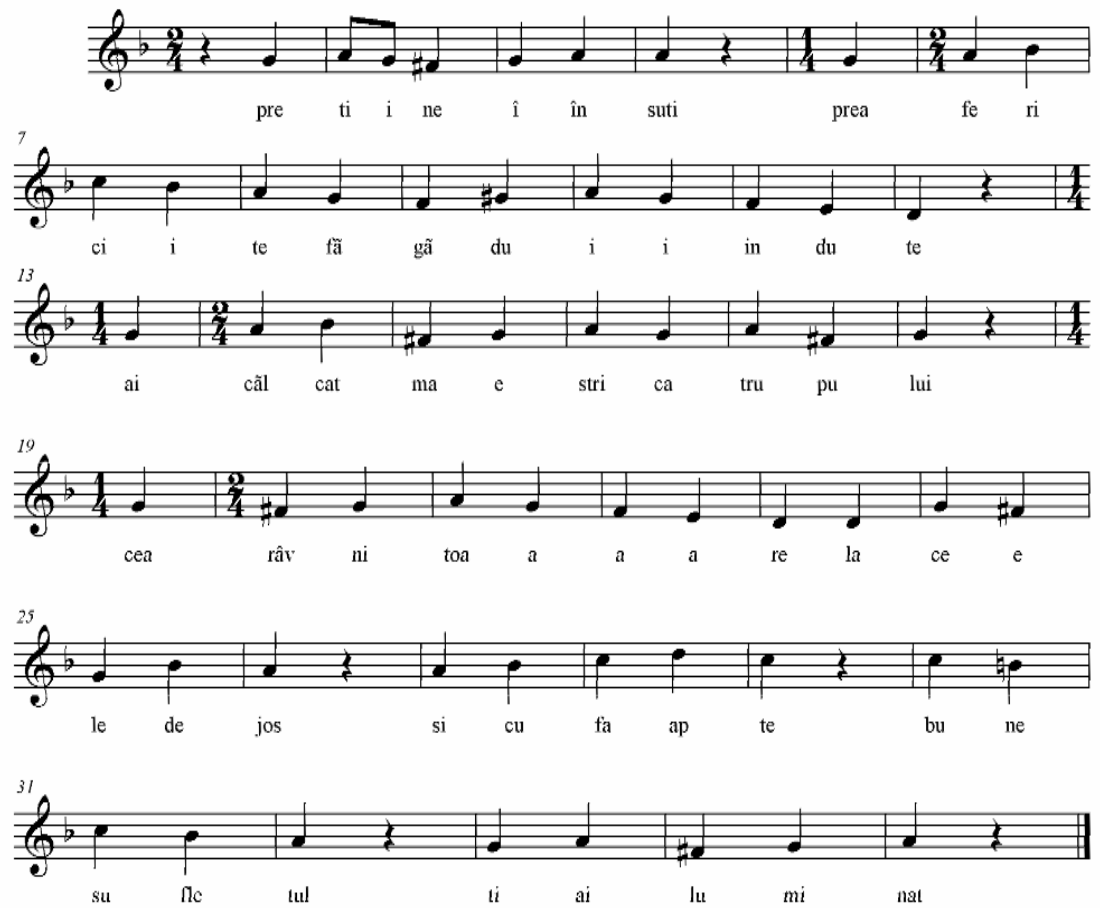

The melodic minor la version being met only in two places, at Troparion and at Prosomia above-mentioned, could be more intuitive from the author side, rather than expressing her knowledge in detail.

The Troparion in the Church chants according to the melodies of the eight voices is graphically transposed in minor sol mode, but the author alters frequently during the song si flat with si natural and with mi natural and cadences on la note, using in fact, the minor la mode with the 6-th step (fa natural-sharp fa). 

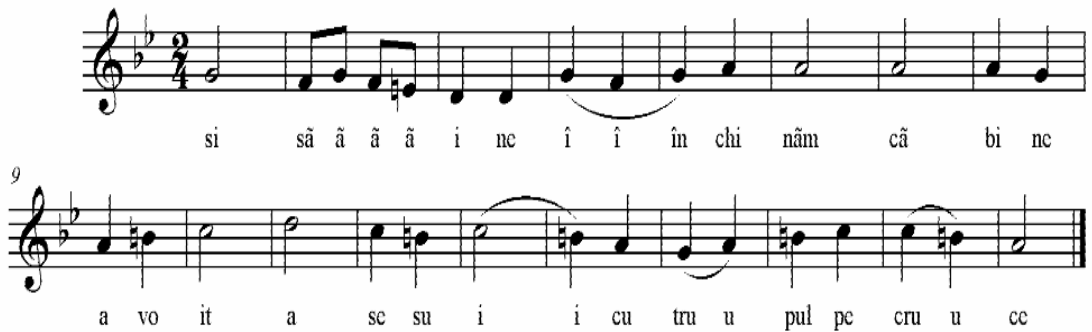

The alternation of fa becar with sharp fa, in the irmological tact and his use in fa becar in the sticherarion tact, leads to the resemblance with the chants from the Church Psaltickhia with the ones from the Standardized Anastasimatarul-Vecernier or Saturday Vespers Chants on eight church voices, and the compositional style encountered in all the Anastasimatarele that have appeared up to know.

\section{The 6-th Voice}

The 6-th voice has 2 scales:

1. the own chromatic scale with base (tonic) on pa (re) (Example 1) and

2. the chromatic scale of the 2-nd voice (which was presented).

Sometimes, we meet at 6 th voice chants with mixt scale: the first chromatic tetracord and the second diatonic (Example 2) or the first diatonic tetracord and the second chromatic (Example 3).

Irmological tact has:

- in own scale imperfect cadences in di (sol), and perfect and finals in pa (re) and

- in the chromatic scale of 2-nd voice, imperfect cadences in di (sol) and perfect and

final in vu (mi). 
Ex. 1

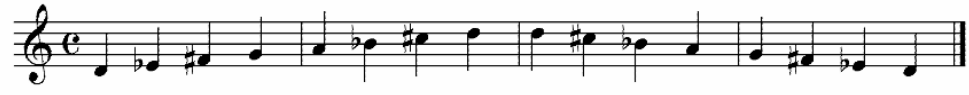

Ex. 2

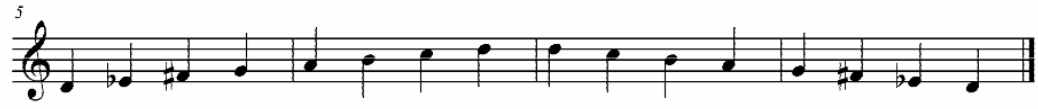

Ex. 3

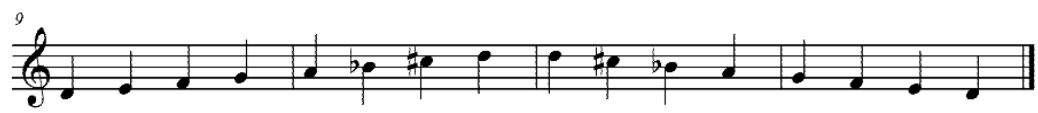

In Church Psaltickhia, the 6-th and 1-st voices transposed, according to him si flat from key, in major fa or its relative minor re. However, during the chant, appear the notes re and mi alterated with flat.

Scale of 6-th voice according to the Church Psaltickhia in Lord, I cried... Let my prayer be set forth before Lord..., stitches and stichera.

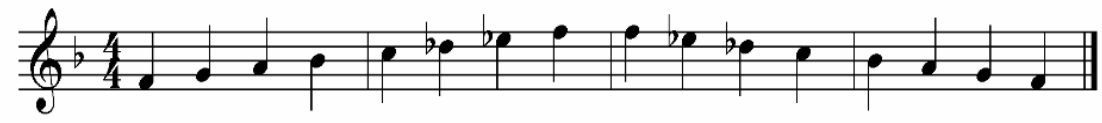

Compared to the steps of the 6-th byzantine voice, Silvestru Morariu-Andrievici encounters difficulties in the reproduction of 6-th voice, as well as in the 2-nd voice. If in the 2-nd voice he succeeds to redeem half of voice, at the 6 -th voice no tetracord is identical to one of the three scales above, neither in ascending, nor in the descending. Just thought from the relative minor re (though it does not give this impression, cadencing on $f a$ ), it is retrieved the first tetracord identical to the first of the third variant, but it is not relevant in the fixation of the voice due to the second tetracord (which contains only do becar and re flat), which is neither specific nor to the 2-nd voice nor to 6-th voice.

The 6-th voice, in Psaltickhia, however, has an oriental melody (somehow chromatic), by descending the 6-th and 7-th steps, combining, in this sense, the chromatic from the second 
tetrakord with the diatonic from the first tetracord. The form of transposing of the 6-th, 1-st voice in Church Psaltickhia would be a combination between the lidic and the mixolidic mode or the acoustic I with the 6-th step lowered.

Example from Lord, I have cried... Church Psaltickhia, pp. 40-41:

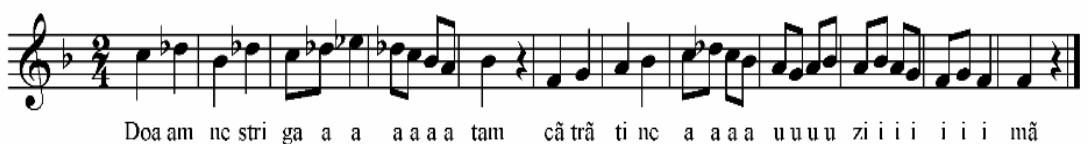

In the Church chants according to the melodies of eight voices, at 6-th voice, Lord, I have cried.... and Let my prayer be set forth before Lord ... are graphically transcribed, according to the armor, in minor la, with the 3-rd (do) and the 7-th (sol) steps alterated in ascending, fact which makes the melody in a way from major la without sharp fa. Internal hearing, however, conducts constantly the author, inside the chant, on mi cadence, the interval sharp la-sol, fa-natural mi, being proper to the 6 -th voice.

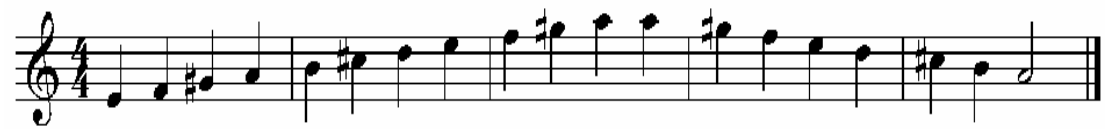

So we can say that Dimitrie Cuntanu combines the melody between two different tetracords:

- one started on the mi note

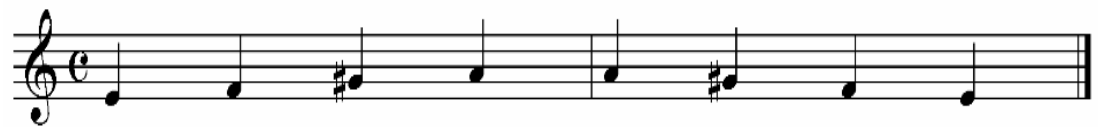

Example of chant in the first tetracord. From Lord, I have cried, 6-th voice,

Church chants according to the melodies of eight voices, $\mathrm{p}$. 14: 

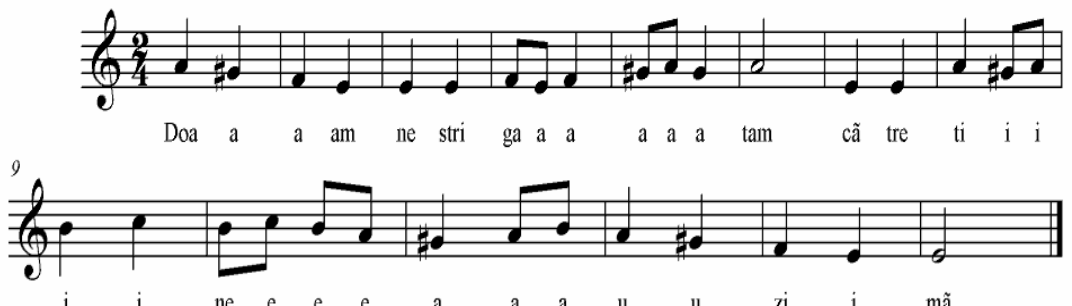

- and the second from the la note.

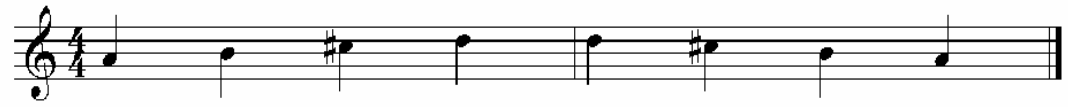

He intuits the second tetracord, but not from upper mi, but from the re, without feeling si flat, fact which which would solve and the second tetracord of the 6-th voice.

Example of chant in the second tetracord. From Let my prayer be set forth before Lord..., 6-th voice, Church chants according to the melodies of eight voices, p. 14.

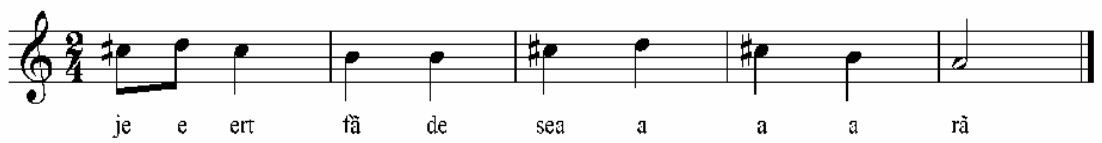

So, we can speak, in this case, only about the half of the 6th voice found in the first tetracord.

The Church Psaltickhia transposes the Troparion of the Resurrection under the form of the 2-nd voice, thought from $\mathrm{fa}$, alternating si flat with si natural, but without altering the sol note, from the first tetracord, with flat. Cadences finaly on the tierce (la).

In Church Chants according to the melodies of eight voices, the Troparion of Ressurection, is transcribed in sol major note.

The Troparion of Ressurection from Church Psaltickhia is similar however, as melodical line, with that from Church Chants according to the melodies of eight voices, from Standardized Anastasimatarul-Vecernier or evening saturday Vespers chants 
on eight church voices and from Anastasimatarele written along the time. Difference are those analyzed above. All free forms of the Troparion alternates cadences between the 5-th step and 3-rd.

Exemples from Ressurection Troparion, 6-th Voice

Example 1: Curch Psaltickhia, pp. 44-45.

Example 2: Church Chants according the melodies of the eight voices, p. 16.

Example 3: Standardized Anastasimatarul-Vecernier or Saturday Vespers Chants on eight church voices, pp. 230-231.

Ex. 1
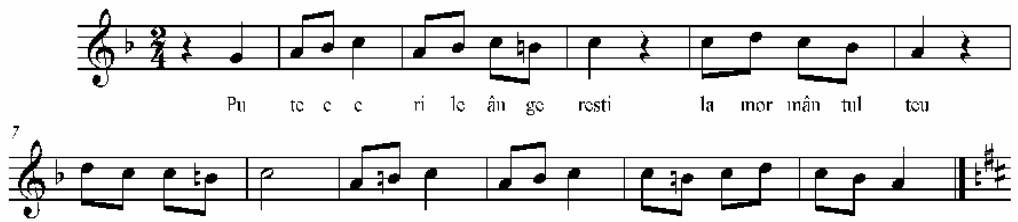

si strầ ja rii au a mor lì câ u lând pre cu ra at tru pul teu

Ex. 2
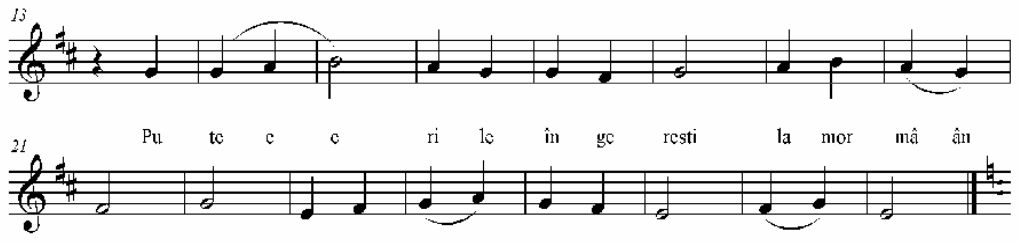

Ex. 3
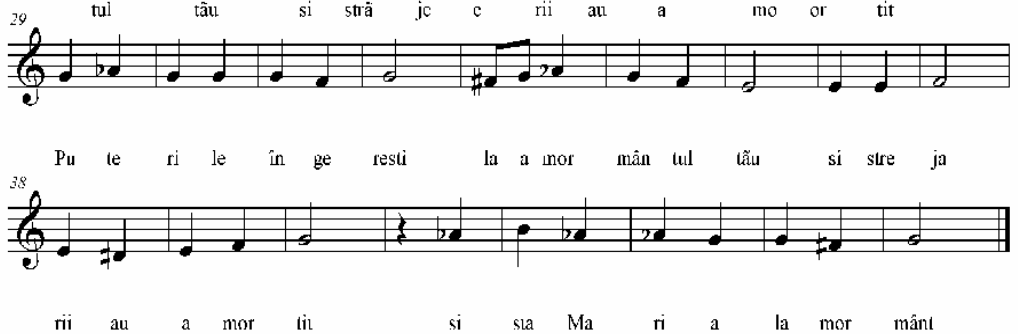

\section{The 7-th Voice}

The chants of the 7-th voice use two forms of scale:

- enharmonic agem form with tonic on ga ( $f a)$ and 
- diatonic form with tonic on zo from inferior octave

By contrast to the 3-rd voice where zo (si) was when ifes (flat), when natural, at the 7-th voice he is permanent ifes (flat)

Both in sticherarion tact and that irmological, chants make imperfect cadences on di (sol) and sometimes on pa (re), and perfect and final cadences on ga $(f a)$. Sometimes the perfect cadence is fixed on $n i(d o)$.

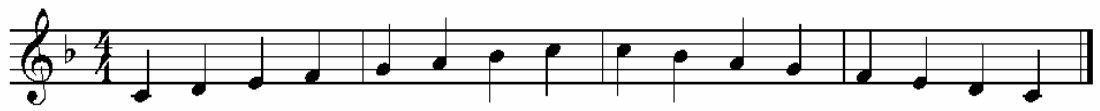

Church Psaltickhia combines elements of the 7-th voice with those of the 8-th voice, fa as from do.

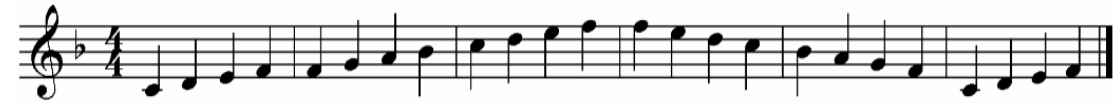

At Lord I cried ... gives the impression that wants to place in the interior of the chant with a final cadence formula met at the 8-th voice (and taking into account the major or minor structure and most part of the eight voices) but related to this formula goes more far and cadences with perfect cadence on the tonic $g a(f a)$ of the 7-th voice. Just thinking in the form of the mode movement from $n i(\mathrm{do})$ to $g a(\mathrm{fa})$, the 8-th voice identical, as a scale, with the 7-th voice. Hence the frequent borrowing of the perfect or final cadence formula from the author, from the 8 th voice to the 7-th voice, and vice versa. The influence of the 8 th with final cadence formula, is so strong in the melody of the 7-th voice, that even at the end of chant, cadences with a formula of final cadence, known, of the 8-th voice, "a confusion that many untrained singers make it today" 6.

Example from Lord, I have cried ... 7-th voice, Church Psaltickhia, p. 46:

${ }^{6}$ Observation made by Nicu Moldoveanu. 


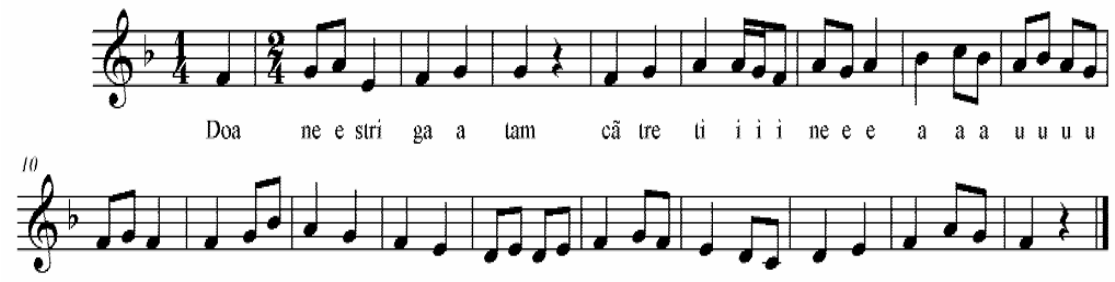

zi i me e e a a a a u u u $x$ i $i$ me e e Doa a a a am ne

In the Church Chants according to the melodies of the eight voices, the 7-th voice, Lord, I have cried ... and Let my prayer be set forth before Lord ..., is also rendered in the major fa tone. The progress of the chants fit in the form of the voice, the author cadencing sometimes falling, interiorly, with imperfect cadence on the $d i(s o l)$, and at the final cadence on the fa tonic. The melodic form of the final formula is different from the other authors.

Example from Let my prayer be set forth before Lord ... , Church Chants according to the melodies of the eight voices, $\mathrm{p}$. 17:
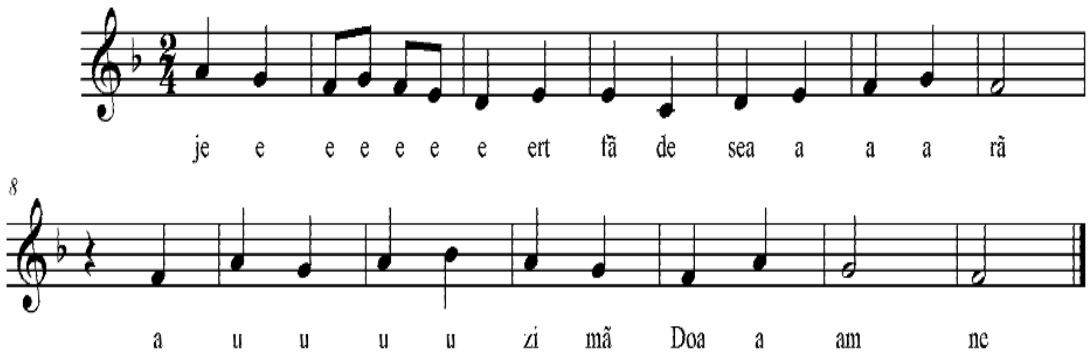

The Troparion of the Resurrection from Church Psaltickhia is so much close to the one from Standardized AnastasimatarVecernier or the Saturday Vespers Chants on the eight church voices, that, being transposed on linear notes, in this form, before six decades of that standardized, you have the impression that the three authors of uniformation preferred him, following the model 
of the Troparion of the Resurrection written by the Metropolitan Silvestru Morariu-Andrievici and adapted, in the meantime, by other authors. Since it does not exist, under this form, in the Anastasimatarele before 1879, we can say that, under the form of taking it over from the Church Psaltickhia and light editing by other authors of Anastasimatare, it reached up to the authors of Standardized Anastasimatar - Vecernier or the Saturday Vespers Chants on the eight church voices, whom they liked and introduced into Vecernier. Even if (to say) they did not have on the operating table the Church Psaltickhia, the similarities lead to the above idea: videlicet, indirectly, by taking over and development of the Resurrection Troparion of 7-th voice was preferred, in this form, by the 3 great teachers. Since several chants in the Church Psaltickhia have obvious similarities to those from the the Standardized Anastasimatar-Vecernier or the Saturday Vespers Chants on the eight church voices, and some formulas are not found in the Anastasimatarele before 1879, we can say that, indirectly, in their opera of standardization, the authors used as a model and part the chants of the Church Psaltickhia, which became a model for the composer Mihai Ursuleac or Father Dimitrie Cuntanu.

And if it so, it can only be good for the unity of church chant at the country level.

At the Troparion of Resurrection, the final cadence, at the two authors is almost identical to the standardized 7-th voice.

Examples of the Troparion of Resurrection on the 7-th voice:

Example 1: The End of the Troparion of the 7-th voice according to: Church Psaltickhia, p. 50.

Example 2: The End of the Troparion of the 7-th voice according to: Church chants according the melodies of the eight voices, p. 18. 
Example 3: The End of the Troparion of the 7-th voice according to: Standardized Anastasimatar-Vecernier or the Saturday Vespers Chants on the eight church voices, p. 262.

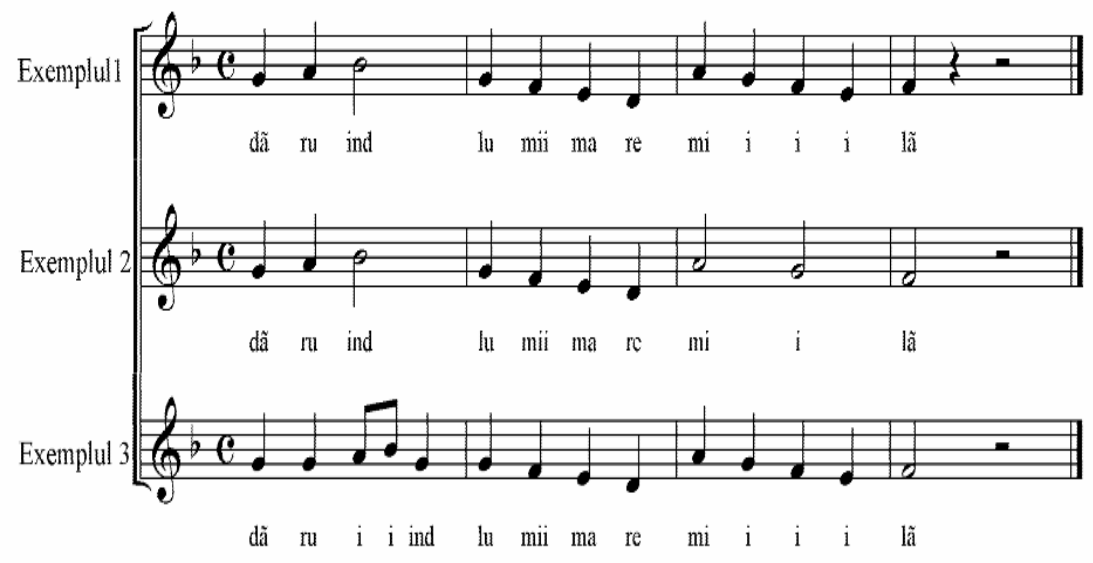

\section{The 8-th Voice}

The 8-th voice corresponds to the major do scale of the linear music. Cadences both in the sticherarion and irmological tact, are as follows:

- semi-cadences on the 5-th stage, di (sol);

- imperfect cadences on stage 3-rd, vu (mi) and

- perfect and final cadence on stage 1-st, ni (do).

The Romanian Psaltickhia transposes the 8-th voice in major fa tonality, resting very often, the interior of the chant on semicadence, the la note. It renders identically with the Standardized Anastasimatar-Vecernierul or the Saturday Vespers Chants on the eight church voices, the final cadence formula. Also, the sticheron Lord, Lord, do not leave us, has a similar 
melody with that from Standardized Anastasimatar-Vecernierul or the Saturday Vespers Chants on the eight church voices.

In the Church Chants according to the melodies of the eight voices, the 8-th voice is rendered in the major re tone.

And Dimitrie Cuntanu oscillates the interior of the chant between semi-cadence and perfect cadence, the shape of the final formula resembling more with one of the variants of the $1-s t$ voice, rather than that of the 8-th voice. In fact, most of its final formulas have this form.

Comparative examples for final cadence:

Example 1: From: Church Chants according to the melodies of the eight voices, Let my prayer be set forth before Lord ..., the 8-th voice, p. 19.

Example 2 From: Standardized Anastasimatar-Vecernierul or the Saturday Vespers Chants on the eight church voices, Dogmatics of the 1-st voice, pp. 30-31.

Exemplu 1
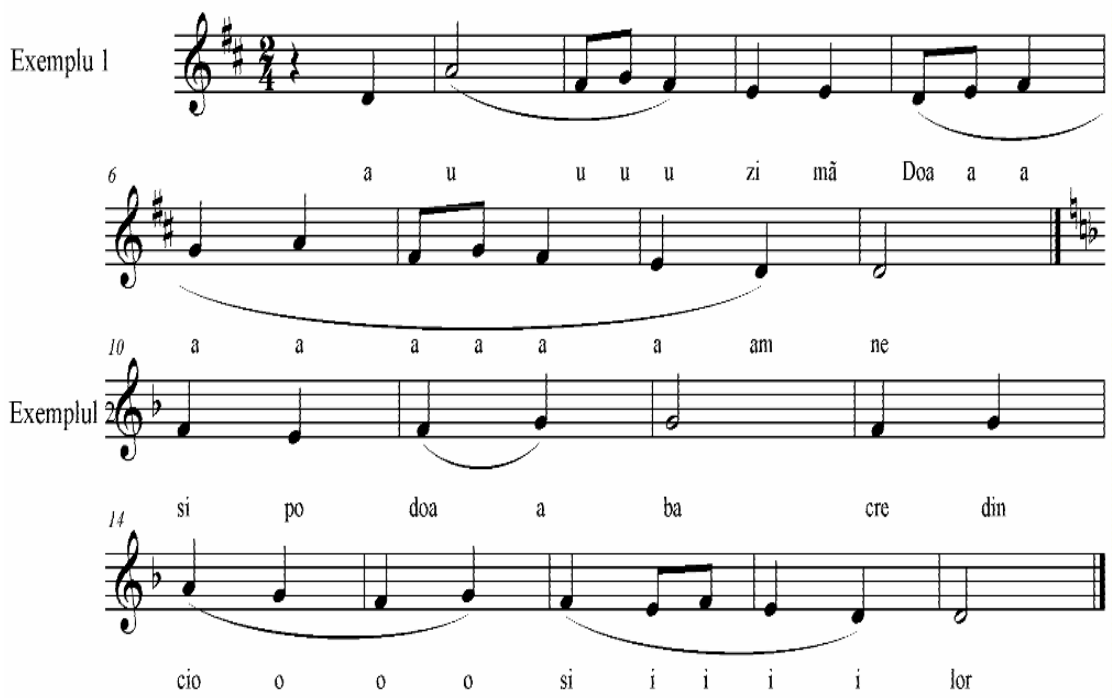
Regarding the Troparions of the three main operas, excepting the formulas of the cadences, there are substantial resemblances concerning the way of melody directing of the to tonic.

Examples of the 8-th Voice Troparion:

Example 1: The Beginning of the 8-th Voice Troparion, from: Church Psaltickhia, p. 54.

Example 2: The Beginning of the 8-th Voice Troparion, from: Church Chants according to the melodies of the eight voices, p. 20.

Example 3: Beginning of 8-th Voice Troparion, from: Anastasimatarul according to Hieromonk Macarie, p. 236.

Example 4: Beginning of the 8-th Voice Troparion, from: Anastasimatarul after Dimitrie Suceveanu, p. 325 (Identical version, taken after Hieromonk Macarie, even if it is identical, I recorded it, to emphasize that about $80 \%$ of the Hieromonk Macarie Anastasimatar chants are identically taken in the Anastasimatar of the protopsalt Dimitrie Suceveanu).

Example 5: The Beginning of the 8-th Voice Troparion, from: Anastasimatarul according to Dimitrie Suceveanu, p. 326 (another variant, own, which somehow brings the beginning fomula of the Troparion from Church Psaltickhia).

Example 6: The Beginning of the 8-th Voice Troparion, from: Anastasimatarul after the Protosinghel Victor Ojog, p. 236.

Example 7: The Beginning of the Troparion of the 8-th Voice, from: Standardized Anastasimatar-Vecernierul or the Saturday Vespers Chants on the eight church voices, p. 294. 
Tx 1

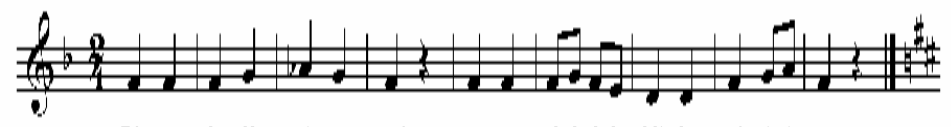

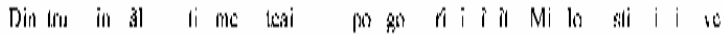
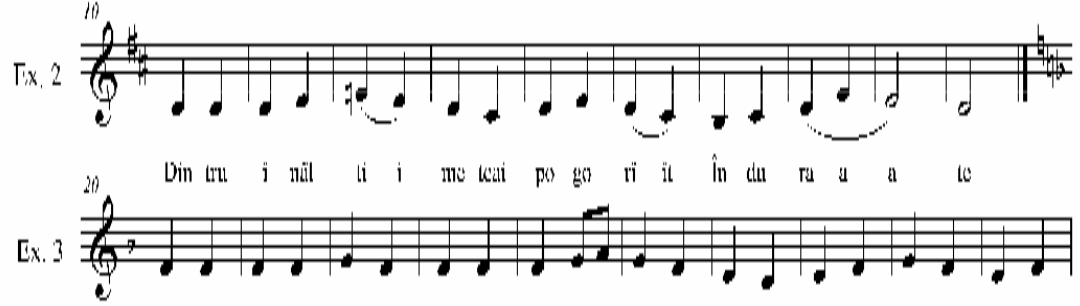

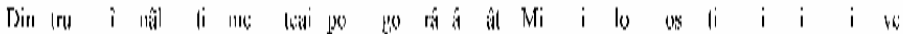

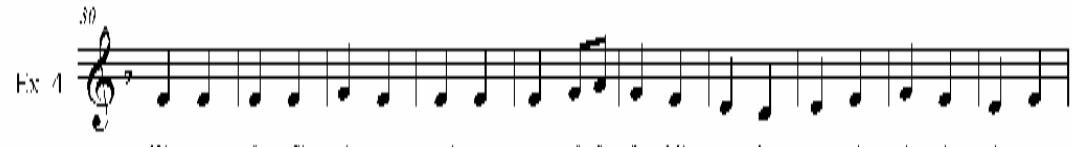
Din เru i näl li me

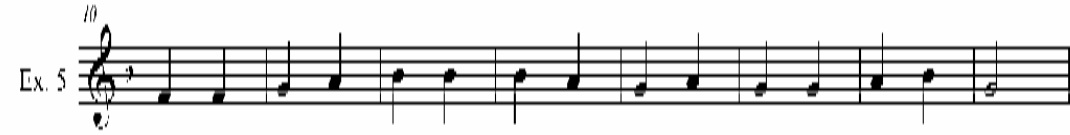

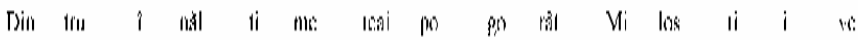

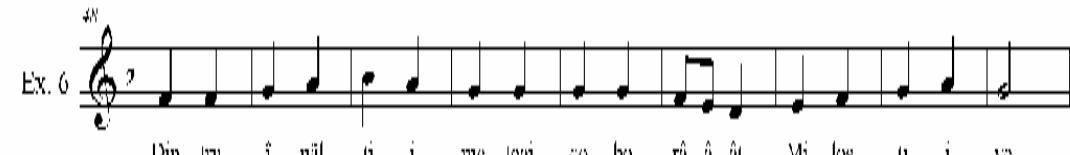

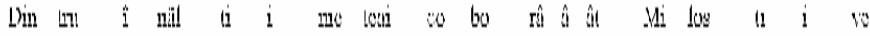

Ex. 7

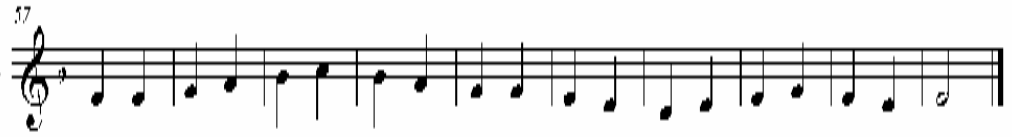

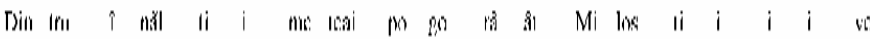

With the object to the structural (typikon) model of 1-st voice, in the Church Psaltickhia, intervened in other voices, excepted Lord I cried and Let my prayer be set forth before Lord, 
... Prosomia and the Troparion of the Resurrection, slight additions, in terms of the number of chants transposed on linear music:

- at the 2-nd voice, the first sticheron of Apostichon, Thy Resurrection, O Christ our Savior ... which is interposed between Troparion and Prosomia ${ }^{7}$;

- at the 4-th voice again appears the intercession with sticheron of the Apostichon: Lord standing on the cross ..., set this time, before Troparion;

- as a novelty element, at the 6-th voice, the Theotokion/Megalynarionappears with And now ... between Troparion and Prosomia;

- at the 8-th voice, between Troparion and Prosomia, is introduced the 5-th Beatitude: Blessed are the merciful ..., with sticheron: Mention us Christ, our Saviour!

The order of Prosomia, on voices, as they are written in the Church Psaltickhia:

- The 1-st voice: $O$ preamărită minune ... and Mormântul Tău Mântuitorule ...

- The 2-nd voice: Când de pre lemn mort... and Casa Efratului ...

- The 3-rd voice: De frumseţea fecioriei tale... şi Fecioara astăzi ...

- The 4-th voice: Ca pre un viteaz ..., Degrab ne întâmpină ... Spăimânta-tu s-a Iosif ... şi Arătatu-te-ai astăzi lumii ...

- The 5-th voice: Bucură-te cămara ... .şi Cuvioase Părinte

${ }^{7}$ Prosomia or Podobie $=$ type of melody, which is tantalizing, especially at biggest feasts, some church chants. It is also called prosomie from the slavonian podobije. 
- The 6-th voice Toată nădejdea ...

- The 7-th voice doesn't has Prosomia

- The 8-th voice: O prea mărită minune ... şi Porunca cea cu taină ... $^{8}$

According to the eight voices order, Church Psaltickhia is structured in this way:

From the page 57 up to 65 page are written the Megalynarion of Sundays on the eight voices, inspired by Romanian authors, especially by Macarie Hiermonk, Anton Pann and Stefanache Popescu and printed in several books of church music.

Comparison:

Example 1: Axion on the 3-rd voice from Church Psaltickhia, p. 59.

Example 2: Axion the 3-rd voice, Agem Asirian by Hiermonk Macarie.

${ }^{8}$ Prosomia processed after Hiermonk Macarie. Taken and edited by several authors including those we mention: Grigore Costea, Nicolae Lungu, Ene Braniste, Chants of the Divine Liturgy and chants of catechesis, in: "Theological Studies", Year III (1951), No. 1-2, pp. 29-60 and No. 3-4, pp. 135-166, and re-edited on several occasions. We remind: The Divine Liturgy and prosmoia of the eight voices, Pitești: The Argeș and Muscel Publishing House, 1996, pp. 129-229; Nicu Moldoveanu, The Divine Liturgy and other church chants, Bucharest: Institutul Biblic și de Misiune al Bisericii Ortodoxe Române Publishing House, pp. 313-359. 
Ex. 1
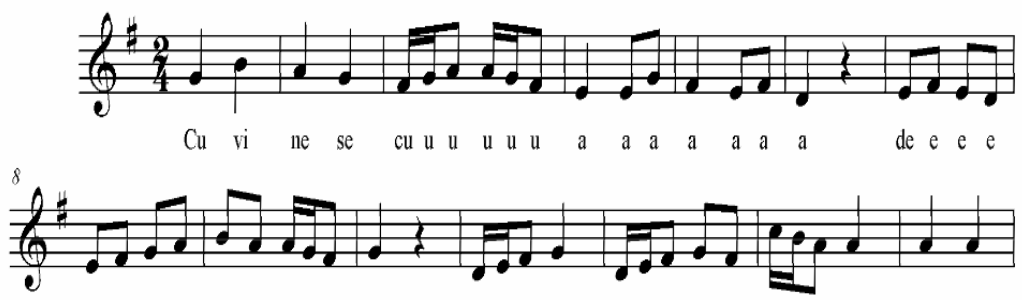

ve e e e ra a a a a at sã ã ã te fe e e ri $\mathrm{i}$ ci i i im Nãs cã

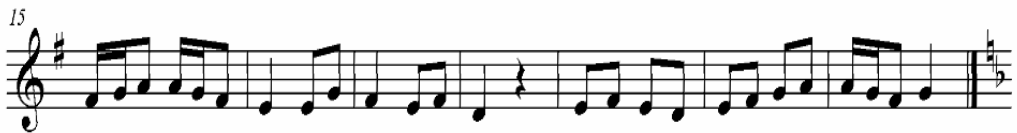

toa a a a a a re e e e e e de Du u u um ne e e e ze e e eu

Ex. 2
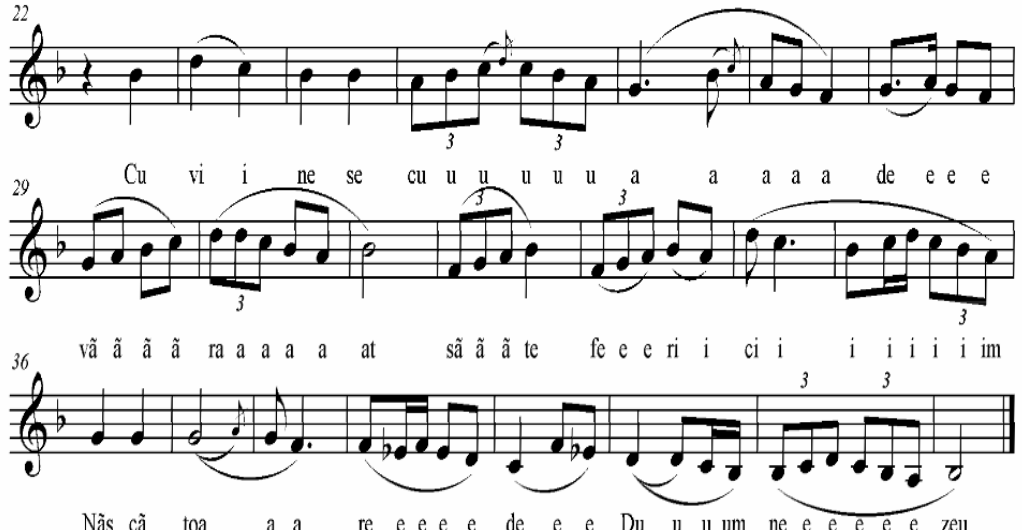

- between the pages 66-77, the Axion of feast, beginning with: at Nativity of our Most Holy Lady the Mother of God and Ever Virgin Mary on 8 September and ending with: The Dormition of our Most Holy Lady the Mother of God and Ever Virgin Mary on August $15^{9}$.

9 They are similar to the Axions composed by Hieromonk Macarie and published by the author in Irmologhion or Catavasieru musicesc, Iaşi, 1848. Retrieved and printed in several editions by various authors, 
Comparison:

Example 1: Axion at the Nativity of Our Lord God and Savior Jesus Christ on December 25, 1-st Voice, from Church Psaltickhia, p. 69.

Example 2: Axion at the Nativity of Our Lord God and Savior Jesus Christ on, 1-st voice, by Hieromonk Macarie ${ }^{10}$.

Ex. 1
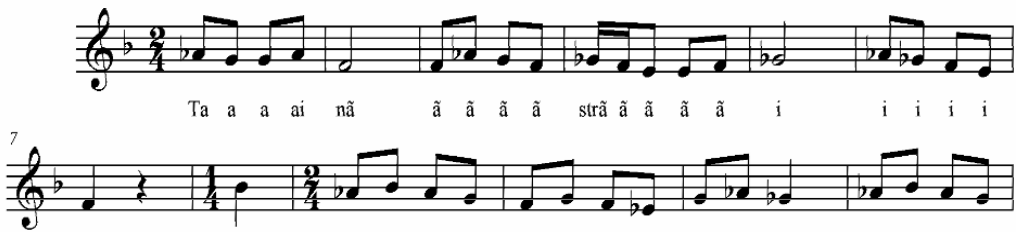

nã

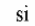

prea a a

lã ã ã ã

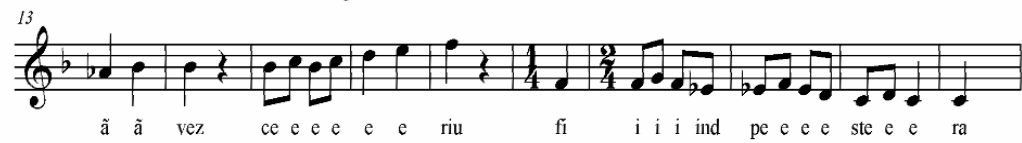

Ex. 2
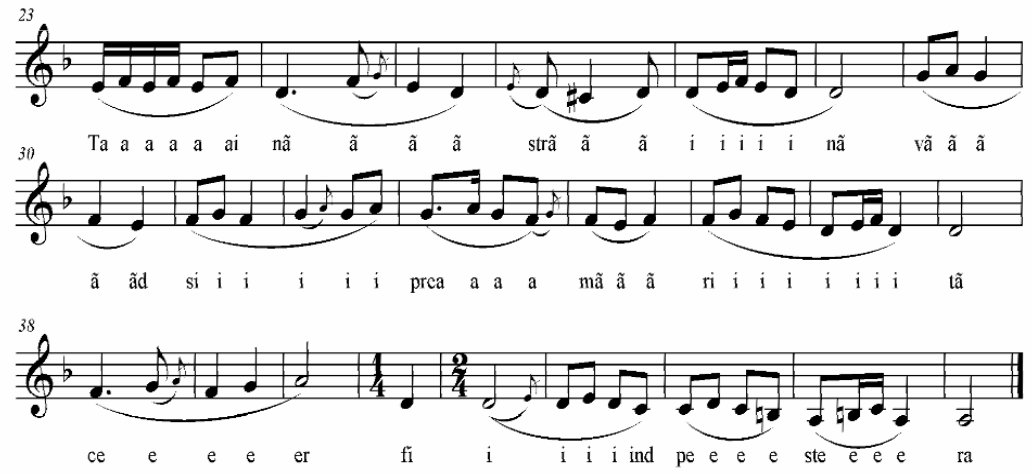

including Ioan Zmeu, Practic Anastasimatar, rarograbnic, operated after Macarie, Anton Pann and Dimitrie Suceveanu, Bucharest, 1903, pp. 236249, Ion Popescu-Pasărea, Practical-Rhythmed Anastasimatar, operated by Ştefan Popescu and printed with permission of the author in Bucharest: The Church Books Printing House, 1899, pp. 49-65; Nicu Moldoveanu, op. cit., pp. 175-205.

${ }^{10}$ Edited in: Ioan Zmeu, op. cit., pp. 237-238; Ion Popescu-Pasărea, op. cit., pp. 52-53; Nicu Moldoveanu, op. cit., pp. 182-183, etc. 
Comparison:

Example 1: Axion in Palm Sunday "Dumineca stelpărilor", 4-th voice, from Church Psaltickhia, p. 73.

Exemplul 2: Axion at Palm Sunday, 4-th voice by Hieromonk Macarie ${ }^{11}$.

Lx. 1
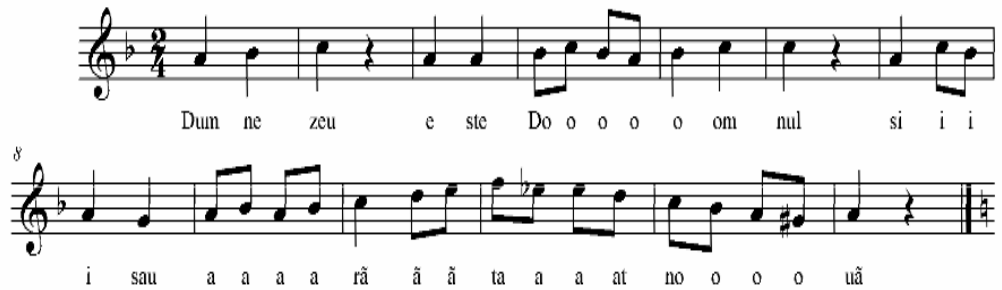

Ex. 2
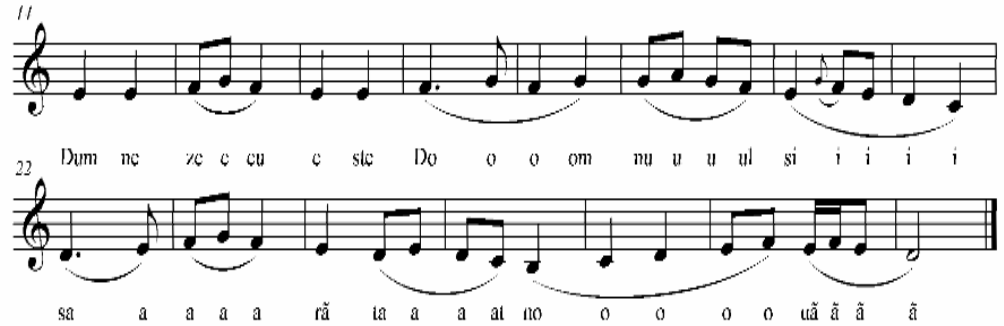

On page 78 we find the Axion at the Liturgy of Saint Basil the Great on the 8-th Voice (in major mi flat), as follows:

- page 79, Cherubim (in major mi flat);

- page 82, Cuminecătoarea (în major re);

The last pages contain some special chants in the following order:

1. page 83. La renduiala de seară. O Gladsome Light... (in major fa with alternate, dominant-relative cadence;

2. pages 84- 87. La mânecândă (Utrenia). Polyeleos. Psalm 134. V. 2; Psalm 135. V. 8; 2. Megalynarion. At Lord Nativity ${ }^{12}$;

${ }^{11}$ Edited in: Ioan Zmeu, op. cit., pp. 244-245; Ion Popescu-Pasărea, op. cit., pp. 58-59; Nicu Moldoveanu, op. cit., pp. 192-193. 
3. At Divine Liturgy:

- pages 88-90. Psalm 102 followed by Antiphon 1 V. 8 are written 10 Stichera from Psalm 102, Bless Lord, my soul ... , similar by melody with the same from Psalm102 by Nectarie Frimu $^{13}$. Psalm 102 from Church Psaltickhia, pp. 88-89, similar with Psalm 102 by Nectarie Frimu op. cit., pp. 1-5.

Another variant, similar to the composer Nectarie Frimu, was translated from Greek by Dimitrie Suceveanu, the Cupbearer ${ }^{14}$;

- pages 90-91. The 2-nd Antiphon on 7-th voice, with: Impărăţiva Domnul în veac ... The 7-th voice indicated, but, in fact, the song of 2-nd Antiphon is also on the 8-th voice.

In Church Psaltickhia, the 7-th and 8-th voices, are written in the major $f a$ tonality, which means that, at the 8-th voice, Silvestru Morariu-Andrievici, uses only the second variant of the voice ( $g a$ as from $n i$ or $f a$ as from $d o$ ), which leads to similar resemblances (in this form) between the two voices, with somewhat different movements in the melody, the formula of the final cadence being the same.

${ }^{12}$ Melody similar to the one from: Dimitrie Suceveanu, Idiomelar, The Pattern of the Neamt Monastery, 1856, p. 233, Reedited by Sebastian-Barbu Bucur, after Dimitrie Suceveanu, in Sinaia, in 1992; Printed in the New Idiomelar, 2-nd Edition, revised, completed, corrected and transcribed by both notations by Nicu Moldoveanu, Bucharest, Institutul Biblic și de Misiune al Bisericii Ortodoxe Române Publishing House, 2007, pp. 464465.

${ }^{13}$ Nectarie Frimu, Anthology or Florilegiu, (Heruvic-Chinoniar), The Saint Neamţu Monastery Printing House, 1840, pp. 1-5. Taken over and Printed by Anton Pann in the Order of the Divine and Holy Liturgy, at his Printing House of Church Music, Bucharest, 1847, pp. 1-5; Nicu Moldoveanu, op. cit., pp. 76-83.

${ }^{14}$ Edited by Ioan Zmeu in Utrenier and Liturgy which includes the most beautiful and chosen songs of most of the church authors arranged in the Typicon order, Buzău: Alessandru Georgescu Publishing House, pp. 175-178. 
Perhaps it was too much for a man's memory to remember, after 40 years, variants of the voices, which we suppose he knew in his youth.

The melody of Antiphons is inspired from Nectarie Frimu, which renders, between Megalynarion ... Both now ... all Psalm $145^{15}$, taken over them and composed by other Romanian authors $^{16}$.

Trisagion hymn.

page 92. Come let us worship and fall down, The

page 92. As many as have been baptized into Christ, a variant inspired by the chants of Nectarie Frimu ${ }^{17}$, then taken over by other composers and improved, without departing too much from the basic melody ${ }^{18}$.

pages 92-94. Father, Son, and Holy Spirit, the Trinity, one in essence and undivided., Great Answers: Anaphora /Eucharistic Prayer and Anamnesis, similar melodies with Great Answers on 8-th voice by Iosif Naniescu, taken over, standardized and sung in a very large proportion, in our Church, along with the Great Answers, on 5-th voice, after Anton Pann ${ }^{19}$

${ }^{15}$ Nectarie Frimu, op. cit., pp. 6-8.

${ }^{16}$ Ion Popescu-Pasărea, Liturgy Book for choir, (5-th voice), Pitești: The Arges Bishopric Publishing House, 1991, pp. 156-157; Ion PopescuPasărea, op. cit., according to Nicu Apostolescu (5-th voice) in Nicu Moldoveanu, Chants of Holy Liturgy, op. cit., pp. 69-76; Sebastian Barbu-Bucur (voice 7-th), in Idiomelar, Sinaia 1992, pp. 84- 88.

${ }^{17}$ Nectarie Frimu, op. cit., p. 20.

${ }^{18}$ Ioan Zmeu, op. cit., p. 185; Ion Popescu-Pasărea, op. cit., p. 12; Nicu Moldoveanu, op. cit., p. 28.

${ }^{19}$ Ioan Zmeu, op. cit., pp. 219-222; Grigorie Costea, Nicolae Lungu, Ene Branişte, op. cit., pp. 46-59; Nicu Moldoveanu, Chants of Divine Liturgy, op. cit., pp. 42-49; Harmonized by various composers, including: Nicolae Lungu, The Psaltic Liturgy for Mixed Chorus, Bucharest: Institutul Biblic și de Misiune al Bisericii Ortodoxe Române Publishing House, 1957, pp. 127-149. These are the Great Answer, often performed in our churches. 
- pages 94-95. One Holy, one is Lord, Blessed is, We have seen the true light, Let our mouths be filled with your praise, o $\operatorname{Lord}^{20}$.

- page 95. The hymn: Many years, with the following words: Mulţi ani facă Domnul pre luminatului nostru Imperat Francisc Josif ânteu prea o svinţitului nostru archiepiscopu... ctitorilor, şi adăugătorilor sântelor biserici preoţilor şi tuturor creştinilor. Domnul să-i păzască întru mulţi ani. (Many years Lord make for our enlighted Emperor Francis Josif to our illustrious archbishop.... to the founders, to the supporters of the churches, of the priests and to all the Christians. The Lord keep them for many years).

- pages 96-97. Axion on the 7-th voice.

\section{Conclusions}

If the entire XIX-th century was concerned with the issue of prints in Romanian language of church chants (starting in 1713), the end of the century brings with itself another problem: transcribing these chants on a new notation.

The organization of religious education and musicalreligious education, in Bucovina, were made especially after the transfer of the church leadership from Rădăuţi to Cernăuti in 1781 and after the establishment near the Church of the theological schools, the Seminary, and then the Theological Institute, which formed the future psaltes, composers, musicians or performers $^{21}$.

As regards the passage to the new notation is known the correspondence between the literate bishops of the time and especially that between the Metropolitan Silvestru Morariu-

${ }^{20}$ Anton Pann, op. cit., pp. 72-74.

21 Vasile Juravle, Religious Music in Bucovina in the XVIII-th-XIX-th centuries, in "Annals of Bucovina", Tom VII, No. 2, 2000, p. 2. 
Andrievici and the Bishop of Roman, Melchisedek Stefanescu, with whom he met in 1881, as well as between the conductor and composer Gavriil Musicescu and the members of the Saint Synod of the Romanian Orthodox Church.

Eusebie Mandicevschi will conduct his first Liturgy in Major La Flat in 1880, even in the presence of the Metropolitan.

On the other hand, at Roman, Veniamin Costache recommended to invest Melchisedec Stefanescu, on February 22, 1879 , as being the most literate bishop of the Romanians ${ }^{22}$.

At his turn, Melchisedec Stefanescu dedicated praise to the memory of Metropolitan Andrei Saguna and his opera, calling him "a man distinguished by erudition and pastoral zeal", in "Gazeta Transilvaniei" newspaper in Brasov, the numbers 20/1 January and 22-nd January/22-nd February 1881.23

In Iasi an important step towards the new notation and choral song had already been made by the establishment of the mixed choir of the Cathedral and the reception of women in the chorus, a phenomenon discussed again at the level of the meetings of the Holy Synod. The Metropolitan of Moldova, Iosif Naniescu, made a Report on the subject, in which he argued, among other things, that if women can not sing in the church, then nuns from monasteries should keep silent.

The phenomenon encompassed many enlightened minds that embraced the idea of reform (imminent at that time) and spread throughout the country, after the beginning period of the late XIX-th century, when were involved the composers Teodor Georgescu, George Ionescu, and so on.

22 Titus N Georgescu, Book Concerns of Bishop Melchisedec and His Library, in "Romanian Orthodox Church", Year XCI (1963), No. 11-12, pp. 1146-1203.

${ }^{23}$ Constantin C. Catrina, Moments and monuments of Byzantine tradition music from Transylvania, in "Byzantion Romanicon", vol. IV, Iași: “George Enescu” Academy of Arts, 1998, p. 32. 
Gavriil Musicescu, Gheorghe J. Dima and Gregory J. Gheorghiu began in 1881 the transposition of the psaltic chnats on a linear notation by addressing a letter of acknowledgment and thanks to their supporter, bishop Melchisedec: "No persons in part, but the whole country and even the whole orthodox world will bless You for the operas, sacrifices and honor that you make to the Orthodox Church in general and to the Romanian one in part. Besides the defense of Orthodoxy, the independence of the Romanian Church, the dignity of the Romanian clergy, and many others, you have also thought of reorganizing the church chants, claiming their transposition on the modern linear notation"24.

They were joined by names such as Gheorghe Dima, Ion Vidu and Dimitrie Cuntanu, who in 1890 published the Church chants according to the eight voices in Transylvania, or Eusebie Mandicevschi, the composer who enriched the choir church music in Bukovina and who, in this sense, agreed with the ideas expressed by Gheorghe Dima: "It is time for us to think about the cultivation of our church music so that our church will rise to the same high level as it should take care ... to listen voice of time and hurry to build a bridge over the gulf that is between modern culture and our church music ..." "25. Continuing on the same idea, the composer Eusebie Mandicevschi showed in the Preface to the Hymns of the Divine Liturgy of John Chrysostom, dedicated to Metropolitan of Bucovina Nectarie Cotarliuc, that he tried to find new forms of church music

${ }^{24}$ The Order of the Saturday evening Vespers on the 8th voices used in the Romanian Orthodox Church, processed and written on the linear notation by Gavriil Musicescu, Gheorghe J. Dima and Gregory J. Gheorghiu. Printed at the expense of the All-Holy D. D. Melchisedek, Bishop of Roman, etc. etc., 1883 (after the title sheet).

${ }^{25}$ Ligia Toma-Zoicaş, Liturgy in front of Eusebie Mandicevschi, in "Byantion Romanicon", vol. IV, Iaşi: "George Enescu” Academy of Arts, 1998, p. 135, from Ana Voileanu-Nicoara, Gheorghe Dima-Life and Opera, Bucharest, State for Literature and Art Publishing House, 1995, p. 192. 
for these hymns taking into account, as far as possible, the needs of the church language in our diocese in the past ${ }^{26}$.

\section{References}

\section{Books:}

1. *** The Divine Liturgy Chants and the prosomia of the Eight Voices, Pitești: The Argeș and Muscel Episcopate Publishing House, 1996.

2. Barbu-Bucur, Sebastian, Idiomelar, reedited according to Dimitrie Suceveanul, Sinaia, 1992.

3. Barcan, Nicolae, Small practic Anastasimatar, Bucharest: The Church Books Printing House, 1922.

4. Frimu, Nectarie, Antology or Florilegiu, (CheroubimChinoniar), The Holy Neamțu Monastery Printing House, 1840.

5. Lungu, Nicolae, Costea, Grigore, Croitoru, Ion, Grammar of the «psaltic» church music. Compared study to the linear notation, Bucharest: Institutul Biblic și de Misiune al Bisericii Ortodoxe Române Publishing House, 1951.

6. Lungu, Nicolae, Costea, Grigore, Croitoru, Ion, Uniformized Anastasimatar - Vecernier or vespers church chants on eight church voices, Bucharest: Institutul Biblic și de Misiune al Bisericii Ortodoxe Române Publishing House, 1953.

7. Lungu, Nicolae, Psaltic Liturgy. Old traditional church melodies, transcribed on the linear notation and harmonized for mixed chorus, Bucharest: Institutul Biblic și de Misiune al Bisericii Ortodoxe Române Publishing House, 1957.

8. Macarie Hieromonk, Anastasimatariu bisericescu, Vienna, 1823, reedited, Buzău, 1856.

${ }^{26}$ Ibid., from the Preface to Liturgy in major fa by Eusebie Mandicevschi. 
9. Macarie Hieromonk, Irmologhionul or Catavasieru musicescu, Iași: The Typography of the Holy Metropoly, 1848.

10. Moldoveanu, Nicu, The Chants of the Holy Liturgy and other church chants, Bucarest, Institutul Biblic și de Misiune al Bisericii Ortodoxe Române Publishing House, 1992.

11. Moldoveanu, Nicu, New Idiomelar, 2-nd Edition, revised, completed, diorrheosized and transcribed on both notations, Bucharest: Institutul Biblic și de Misiune al Bisericii Ortodoxe Române Publishing House, 2007

12. Musicescu, Gavriil, Dima, Gheorghe, J., Gregory, Gheorghiu, I., The arrangement of the saturday evening vespers on the 8 voices used in the Romanian Orthodox Church, processed and written on linear note by Gavriil Musicescu, Gheorghe J. Dima and Gregory J. Gheorghiu. Printed at the expense of his all-holly D. D. Melchisedek, Bishop of Roman, etc. etc., Roman, 1883.

13. Ojog, Victor, Anastasimatar, The Monastery of Neamt Printing House, 1943

14. Pann, Anton, The Ordinance of the Holly and Divine Liturgy, To His Typography of Church Music, Bucharest, 1847.

15. Popescu-Pasărea, Ion, Practic-rhythmed Anastasimatar, operated by Ștefan Popescu and printed with permission of the author, Bucharest: The Church Books Printing House, 1899.

16. Popescu-Pasărea, Ion, The Liturgy of Choir, Pitești: The Argeș Bishopric Publishing House, 1991.

17. Suceveanu, Dimitrie, Anastasimatariu bisericescu, Iaşi: The Holy Metropoly Printing House, 1848.

18. Suceveanu, Dimitrie, Idiomelar, The Pattern of the Neamţ Monastery, 1856.

19. Voileanu-Nicoară, Ana, Gheorghe Dima. Life and opera, Bucharest: The State for Literature and Art Publishing House, 1995. 
20. Zmeu, Ioan, Anastasimatar practic, rarograbnic, arranged by Macarie, Anton Pann and Dimitrie Suceveanu, Bucharest: Typography of Church Books, 1903.

21. Zmeu, Ioan, Utrenier and Liturgy Book, which includes the most beautiful and chosen chants of most church authors, arranged in the order of the typicon, Buzău: The Alessandru Georgescu Publishing House, 1892.

\section{Studies:}

1. Catrina, C. Constantin, "Moments and monuments of the music of byzantine tradition from Transilvania", in "Byzantion Romanicon", vol. IV, Iaşi, "George Enescu" Academy of Arts, 1998.

2. Costea, Grigore, Lungu, Nicolae, Braniste, Ene, "The Church Chants and chants of catechesis", in "Theological Studies", Year III (1951), No. 1-2 and No. 3-4.

3. Georgescu, Titus, N., "The concerns for book of the Bishop Melchised and his library", in "Romanian Orthodox Church", Year XCI (1963), No. 11-12.

4. Juravle, Vasile, "Religious Music from Bucovina in the XVIIIth-XIX-th centuries", in the "Annals of Bucovina", Romanian Academy Publishing House, Tom VII, No. 2, 2000.

5.Toma-Zoicas, Ligia, "Liturgy in major $\mathrm{Fa}$ by Eusebie Mandicevschi", in "Byzantion Romanicon", vol. IV, Iași, "George Enescu" Academy of Arts, 1998. 
Costel-Mirel

NECHITA

\section{ANNEXES}

O Lord, I have cried unto Thee ... and Let my prayer be set forth..., 6-th voice, from Church Psaltickhia, pp. 40-41:

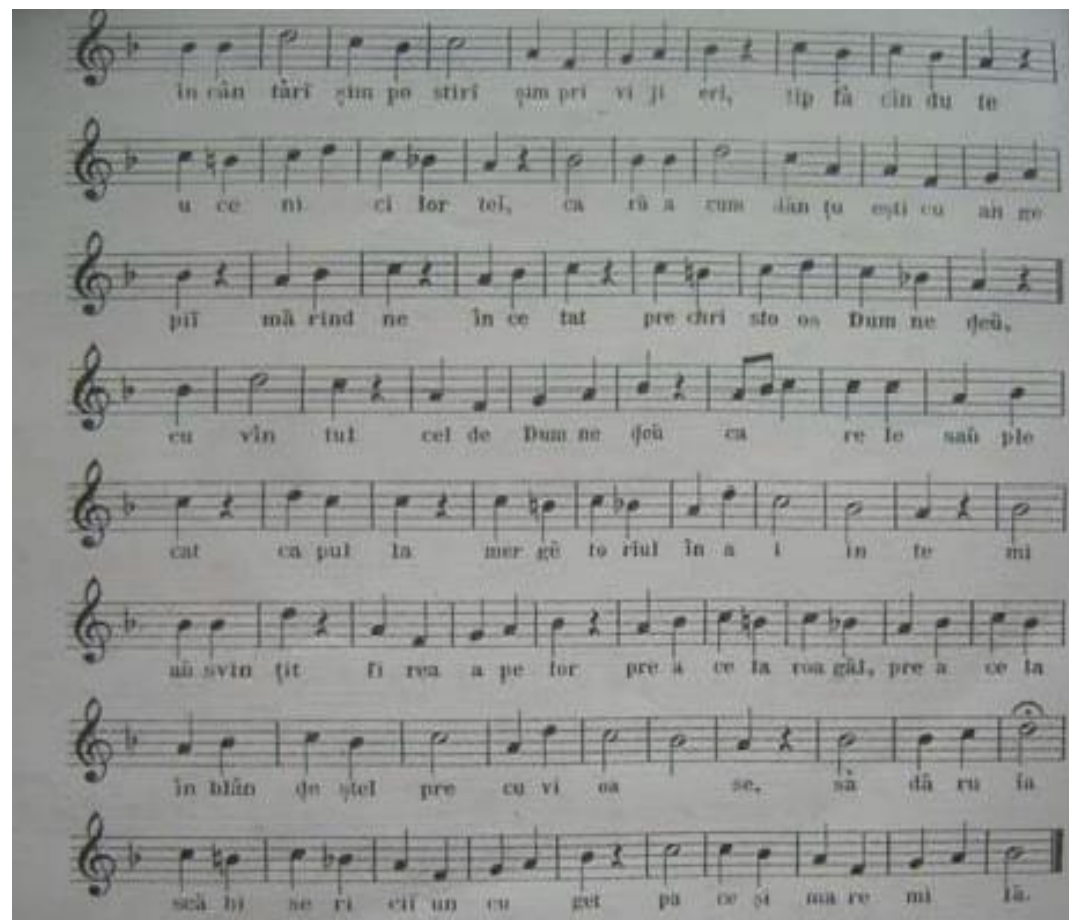

\section{Glasul al VI.}

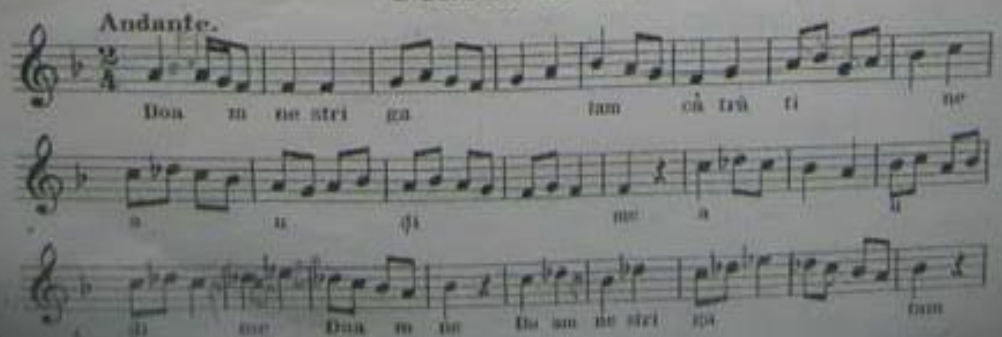


(6)

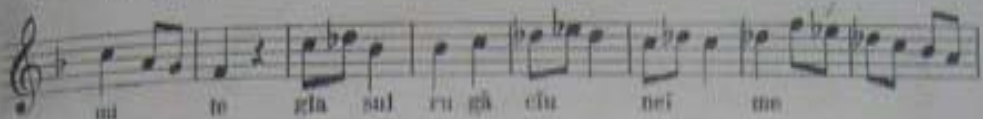

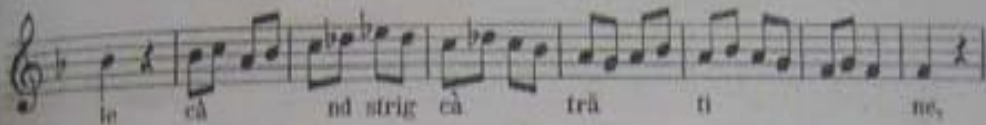

(0)

(o. Andante.

G.

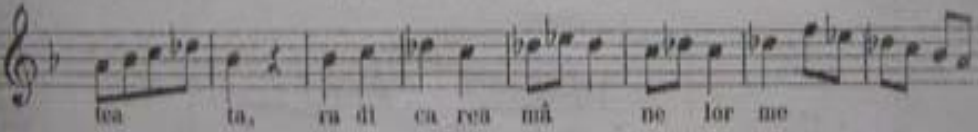

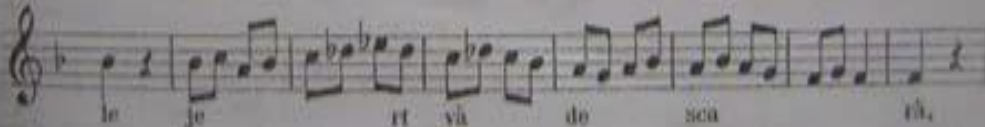

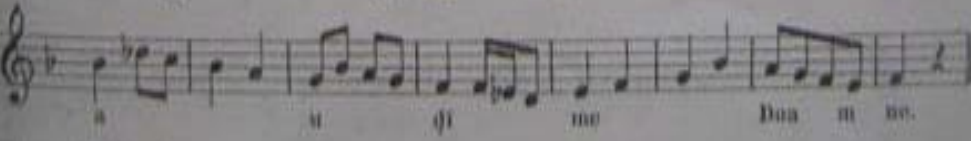

1) Alleireo.

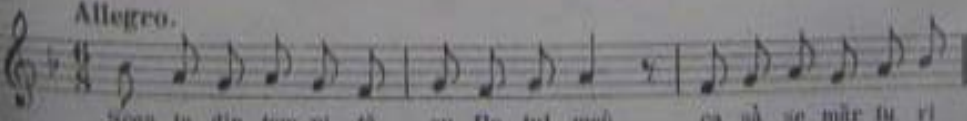

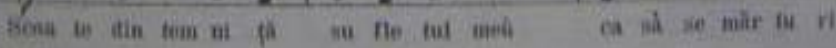

A Auctante.

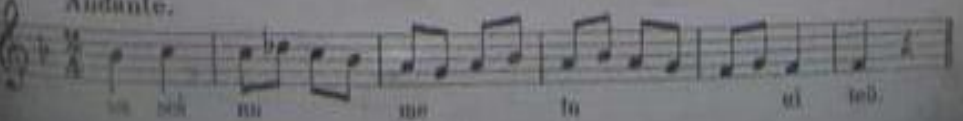


Costel-Mirel

NECHITA

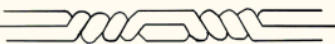

Troparion of Ressurection, 6-th voice, from Church Psaltickhia, pp. 44-45.

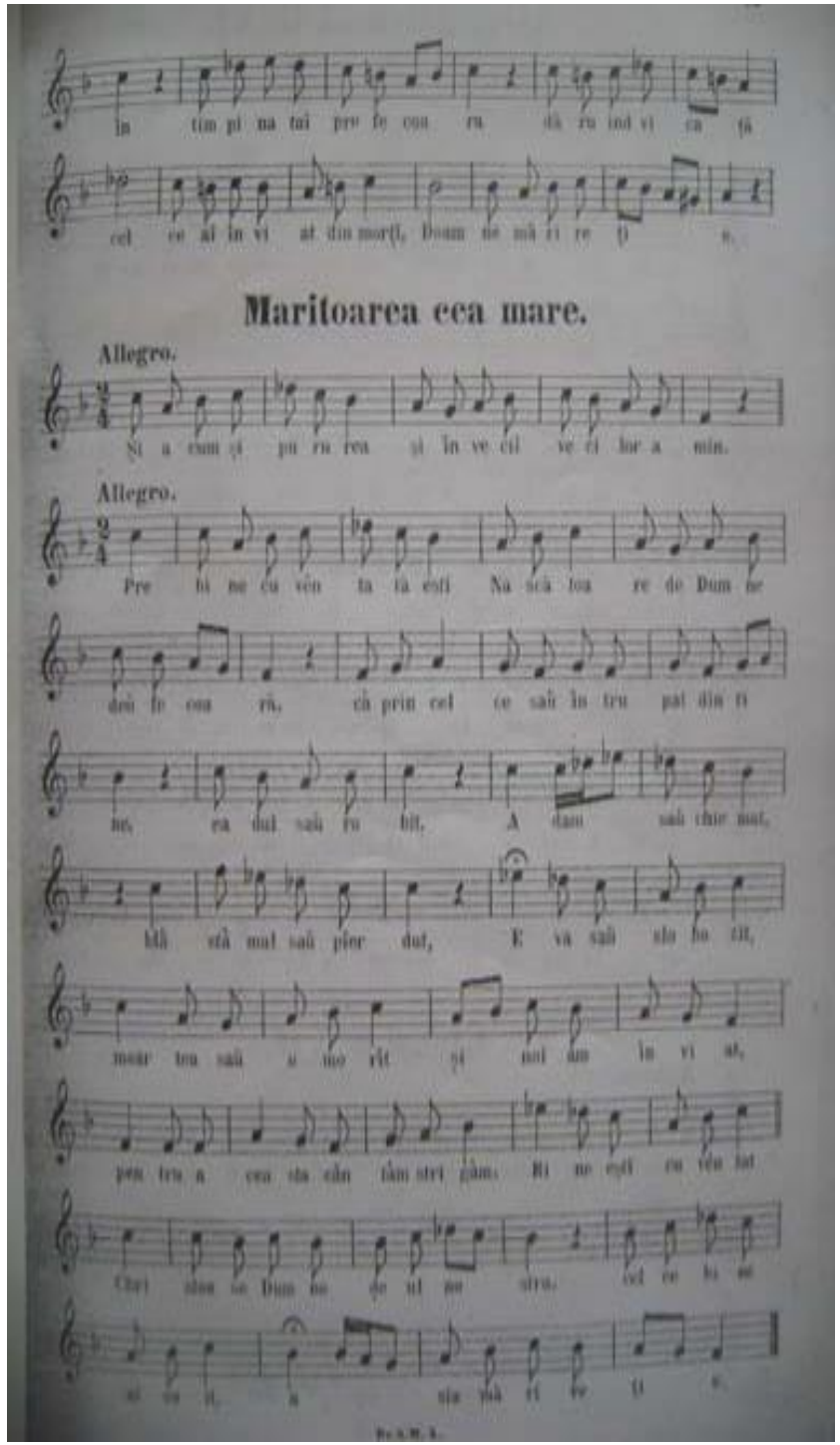




\section{of the metropolitan of Bucovina}
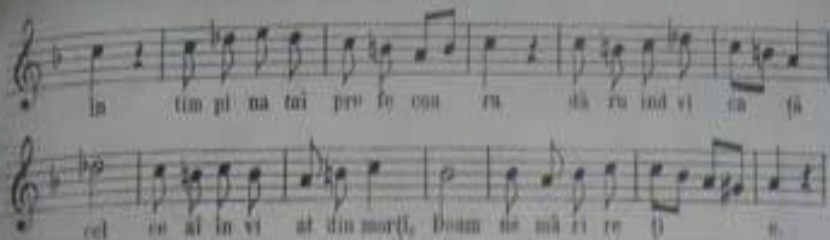

\section{Maritoarea cea mare.}

Allegro:
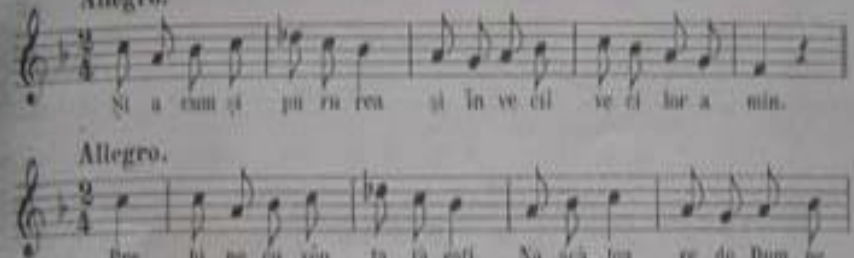

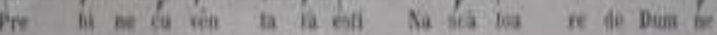

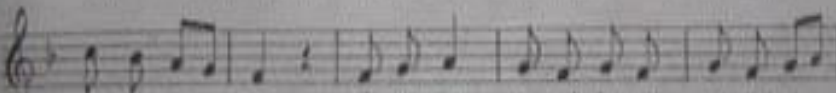

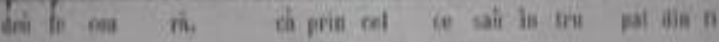
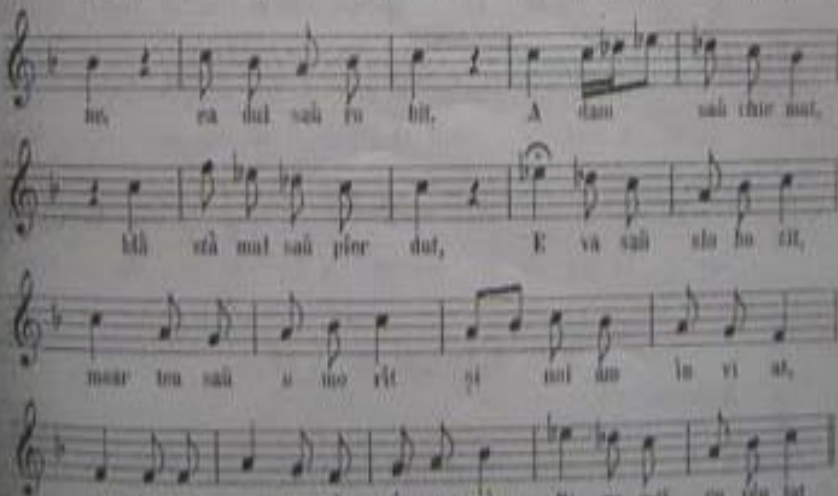

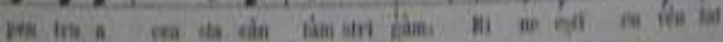
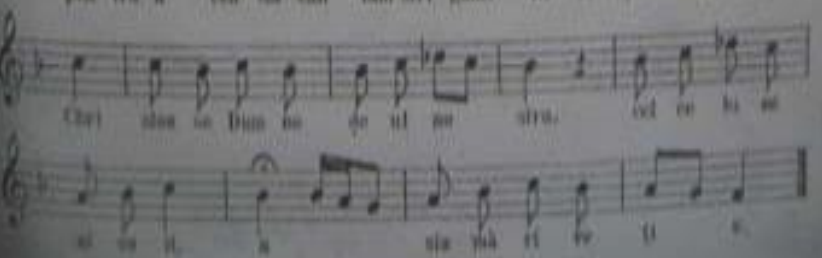
Costel-Mirel

NECHITA

$\longrightarrow 000 \mathrm{arn}$

Exapostilar, 1-st voice and... Saint is our Lord ... and With the disciples to go up ..., p. $87^{27}$.

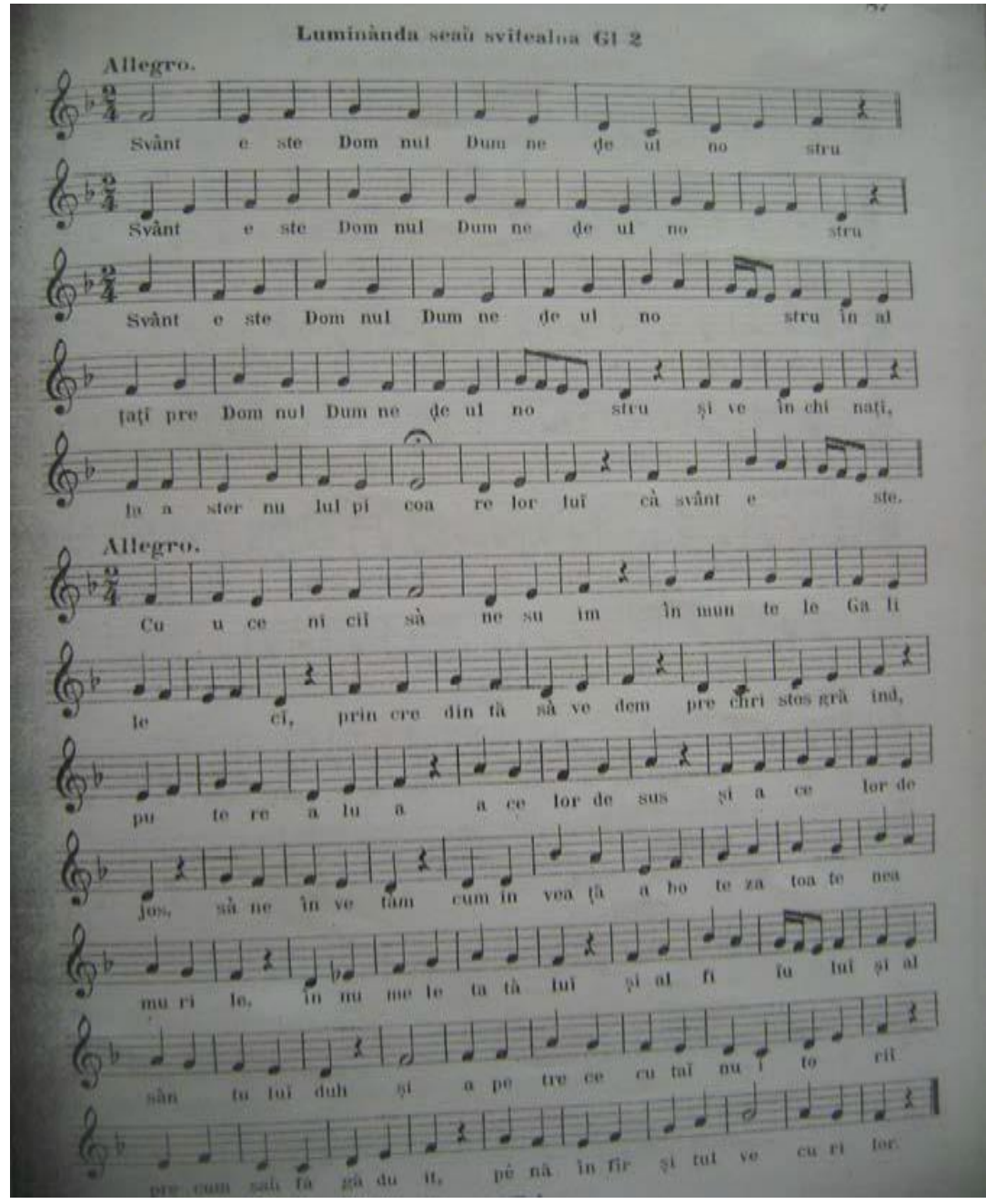

27 A similar melody to that of Macarie Hieromonk, Anastasimatariu bisericescu, p. 256. 
Come let us worship and fall down, The Trisagion hymn şi As many as have been baptized into Christ, Son, and Holy Spirit, the Trinity, one in essence and undivide. The Great Anwers: Anaphora /Eucharistic Prayer from Church Psaltickhia, p. 92.

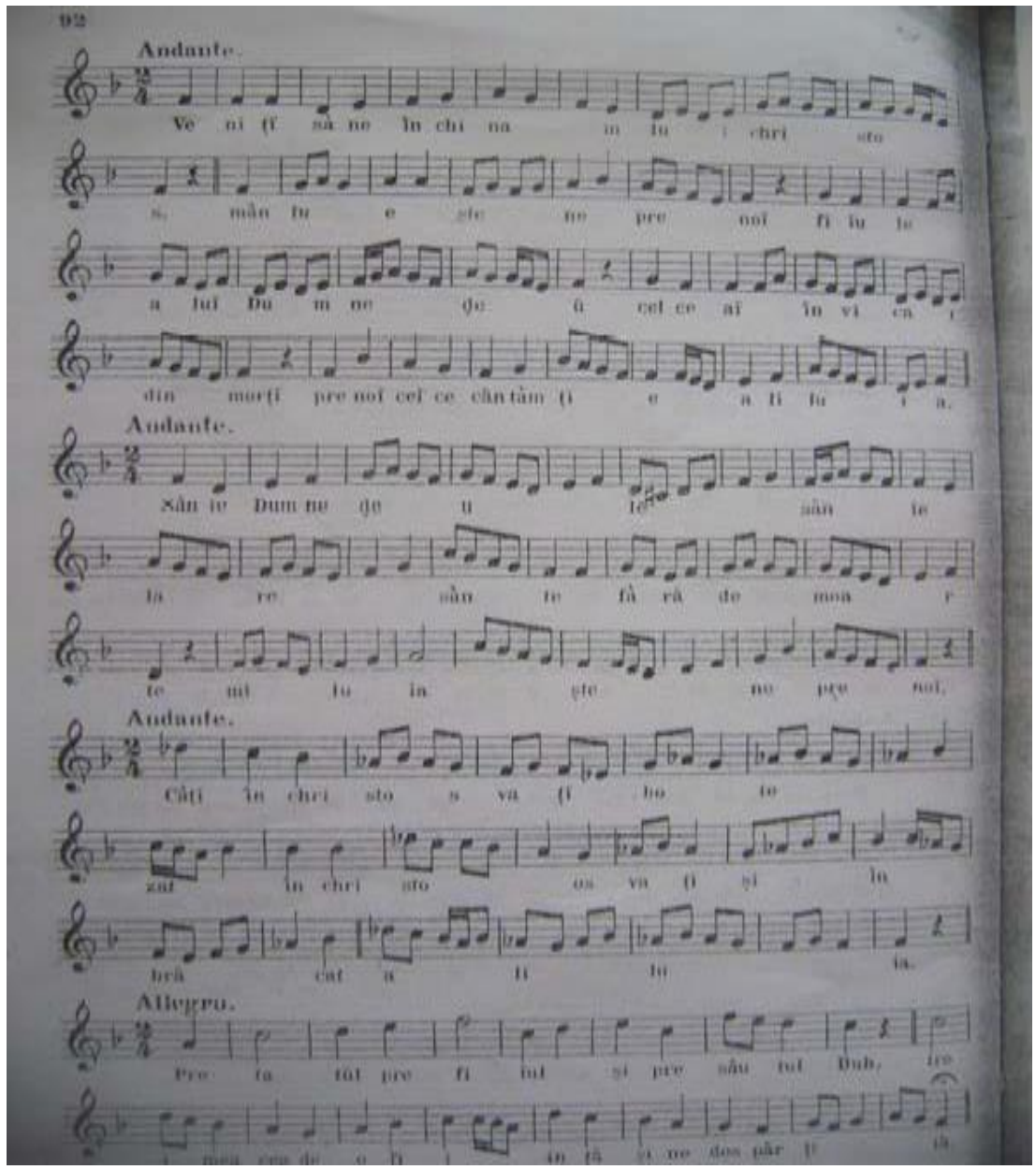


Costel-Mirel

NECHITA

$\Rightarrow 000000$

Allegro.

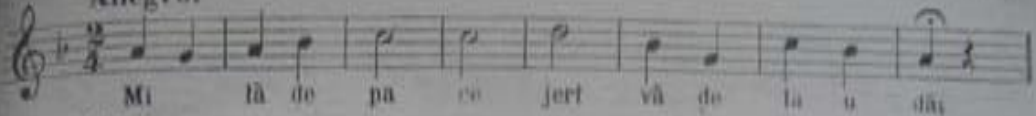

Allegro.

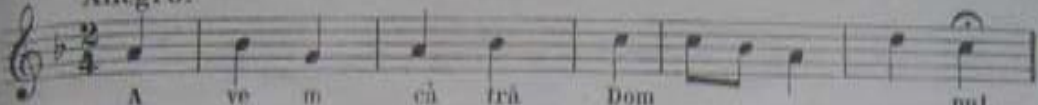

Dom nul.

(1llegro.

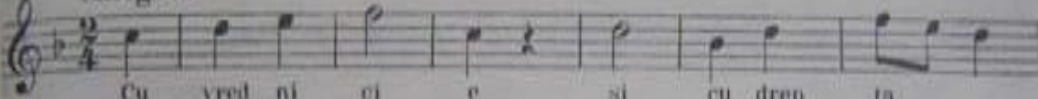

Cu vred ni oi a cu drep in

$\left(\begin{array}{l}\text { (Q) } \\ \text { a }\end{array}\right.$

(6)

si fi lui sil wăn fu lui buh. tro i nei cei

(6)

de $\theta$ fi in ta bi ne des nar ti ta.

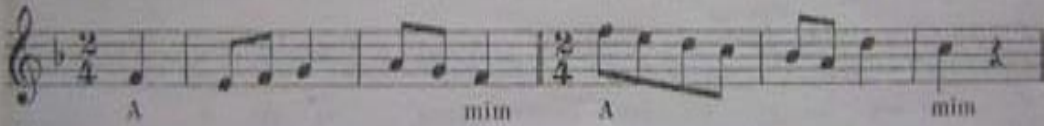

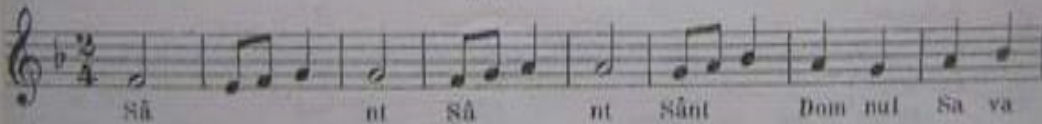

(g)

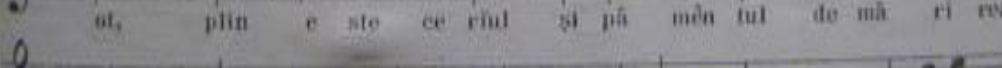

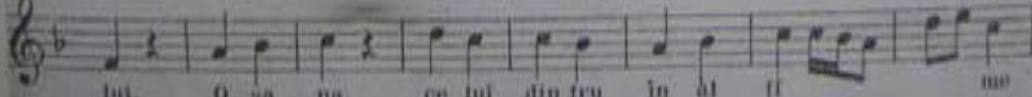

(6)

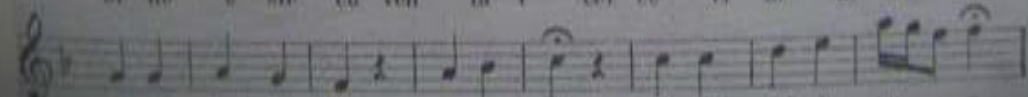

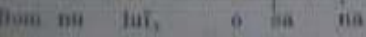

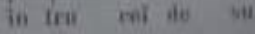

